\title{
Az Észt információs társadalom fejlődése az 1990-es évek óta
}

Az 1990-es évek óta Észtország figyelemreméltó sikereket ért el az információs társadalom fejlődése terén. A tanulmány leírja a kulcsfontosságú területeken elért eredményeket és elemzi a fő tényezőket, amelyek lehetővé tették ezt a fejlődést A szerzők szerint közrejátszott ebben az állami szektor, a gazdasági szereplők aktivitása, a műszaki felkészültség és számos más társadalmi-kulturális adottság is. Az észt információs társadalom fejlődésének zászlóshajói a távközlés és a bankszektor, amelyek fontos szerepet játszottak a számítógépes írástudás növelésére irányuló és az új lehetőségek tudatosítását célzó kezdeményezésekben. Az állami szektor tevékenysége szintén döntő fontosságú volt a kedvező jogi szabályozási környezet megteremtésében, valamint az innovatív e-szolgáltatások bevezetésére indított infrastrukturális programokban is. Az állami szektorban folyó fejlesztéseket hathatósan elősegítették egyes nem-kormányzati szervezetek is. Fontos szerepet játszottak továbbá a lakosság már meglévő IKT-készségei, valamint az országban folyó K+F tevékenység, amelynek nagy részét még a szovjet idők öröksége alapozta meg.

Kulcsszavak: Észtország, információs társadalom, gazdaság, benchmarking

\section{Szerzői információ:}

Tarmo Kalvet

A Tartui Egyetemen, Észtországban végzett közigazgatási és szociálpolitikai tanulmányokat, jelenleg a Tallinni Múszaki Egyetem e-kormányzati doktori tanulmányokat folytató tudományos munkatársa és a PRAXIS igazgatótestületének tagja, az innovációs program vezetôje. Korábban az Archimedes Alapítványnál dolgozott elemzóként az IKT-szektor „Észt e-vikingek” (Estonian eVikings) címú klasztertanulmányának elkészítésében (2001-6/2002), projektmenedzserként vezette az információs társadalom helyzetének európai felmérése, a European Survey of Information Society észtországi munkálatait, és közremúködött a 5FP Information Society Technologies program észt nemzeti kontaktpontjának munkájában (1999-2000).

tarmo@praxis.ee

Így hivatkozzon erre a cikkre:

Kalvet, Tarmo. „Az Észt információs társadalom fejlődése az 1990-es évek óta”.

Információs Társadalom VIII, 3. szám (2008): 51-81.

= https://dx.doi.org/10.22503/inftars.VIII.2008.3.5

A folyóiratban közölt müvek

a Creative Commons Nevezd meg! - Ne add el! - Így add tovább! 4.0

Nemzetközi Licenc feltételeinek megfelelően használhatók. 
Tarmo Kalvet

\section{Az észt információs társadalom fejlódése az 1990 -es évek óta}

\section{Bevezetés}

A „Hálózat az információs társadalom tanításáért” (Network for Teaching Information Society, NETIS, 2006-2008) projekt 'célja az egyetemi és fóiskolai hallgatók ismereteinek bôvítése az információs társadalom témakörében, a tárggyal kapcsolatos tudásukat megalapozó és elmélyítô „Információs társadalom” címú kurzus bevezetése révén a felsőoktatási intézményekben. A projekt küldetésnyilatkozata szerint:

Európa jövôje a kompetens és céltudatos emberektól függ, akik képesek irányítani az információs társadalom fejlődését. A NETIS célja a diákok, az oktatók, a kutatók, a szakemberek és a szélesebb közösség ismereteinek és készségeinek bốvítése egy széles körben hozzáférhetố releváns, innovatív és fenntartható e-learning kurzus bevezetésével az információs társadalom tárgykörében. Ezt a kurzust konstruktivista szemlélettel, moduláris szerkezetben építjük fel, kihasználva a nemzetközi együttmúködésben rejlő lehetôségeket az igényekhez alkalmazkodó, hiteles és megbízható tartalom kidolgozásához. A NETIS ezáltal tudatosítani kívánja a résztvevókben az információs társadalom fejlődése következtében a mindennapi életet érintô hatásokat, hogy képessé váljanak azokra reflektálni.

E tanulmány célja a hallgatók és a szélesebb közönség tájékoztatása az információs társadalom kiépítése terén elért észtországi eredményekról, amelyeknek a megismerése kiegészítésül szolgálhat a kurzus tankönyvében foglaltakhoz. Amellett, hogy szinte valamennyi témát érintjük, amelyek a tankönyvben szerepelnek, az e-kormányzati szolgáltatások ${ }^{2}$ témakörét részletesebben tárgyaljuk, mivel ezek megvalósítása terén Észtország komoly sikereket ért el, és kitérünk két további témára is. Ezek közül az első a digitális megosztottság és az információs környezet kérdésköre (lásd 6. pont), a második pedig az adatvédelem és a hálózati biztonsảg Észtországban kiemelkedő fontosságú témája, beleértve a kiberháború újabban felmerülő kérdéseit: ezzel a 7. pontban foglalkozunk.

A fejlődés több mint 15 éves folyamatát egyetlen viszonylag rövid tanulmányban szinte lehetetlen összefoglalni, ám a sikertényezók, az ösztönzók és a korlátok, valamint a jövốbeli kihívások megértéséhez ilyen hosszú idốre kell visszatekintenünk.

${ }^{1}{ }^{1}$ Részletesebben lásd http://www.ittk.hu/netis/

${ }^{2}$ Az e-kormányzat az információs és kommunikációs technológiák közigazgatási alkalmazásaként határozható meg, beleértve a közszolgáltatások és a demokratikus folyamatok javítása, valamint a közérdekű politikai törekvések támogatása érdekében végrehajtott szervezeti változásokat és az eszközök alkalmazásához szükséges új készségeket is (European Commission COM [2003] 567). Felöleli tehát a közigazgatás, a demokrácia, a kormányzat és a politikai döntéshozatal dimenzióit egyaránt. 
A jelen tanulmány kiindulópontja az, hogy az információs társadalom fejlődése terén elért észt sikereket széles körben elismerik. ${ }^{3} \mathrm{Az}$ évek során Észtország valóban igen magas pozíciót vívott ki magának az e-fogadókészség (e-readiness) ${ }^{4}$ mértéke tekintetében, nem csupán a közép- és kelet-európai országok között, hanem az EU régi tagállamaival és az IKT terén vezetố szerepet játszó más országokkal való nemzetközi összehasonlításban is. ${ }^{5}$

\section{Észtország helyzete nemzetközi összehasonlításban}

Jelen tanulmányunkban bizonyos mértékig arra az átfogó kutatási projektre támaszkodunk, amelyet a Tallinni Múszaki Egyetem és a politikai tanulmányok PRAXIS központja közösen végzett az e-kormányzat és az e-egészségügy helyzetéról Észtországban. ${ }^{8} \mathrm{~A}$ „Következő lépések az információs társadalmi szolgáltatások fejlesztésében az új tagországokban az e-kormányzat és az e-egészségügy terén" (Next Steps in Developing Information Society Services in the New Member States: The Cases of eGovernment and eHealth 2005-2007) címú projekt az Európai Bizottság általános közös kutatási központját irányító igazgatóság keretében múködő Elôretekintô Technológiai Tanulmányok Intézete (Institute of Prospective Technological Studies, IPTS) megbízásából végzett nemzetközi kutatás részét képezte. Az ebból a vizsgálatból leszûrt következtetéseket kiegészítik egy másik, a PRAXIS által végzett kutatás és más felmérések eredményei is, amelyekben a szerző 1997 óta részt vett. Így

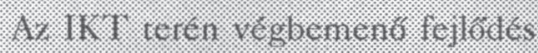

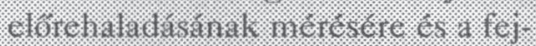

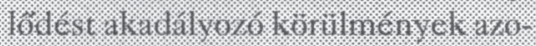

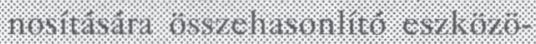

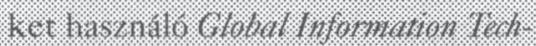

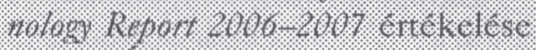

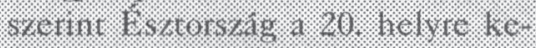

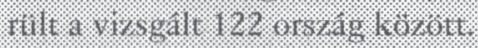

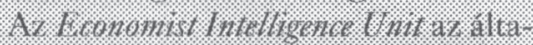
1.

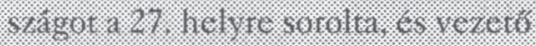

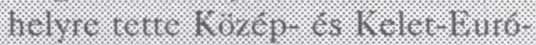

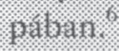

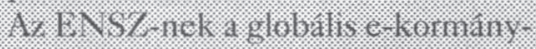

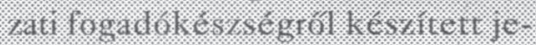

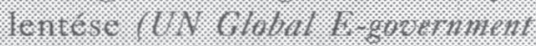

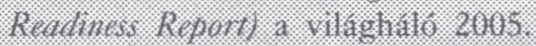

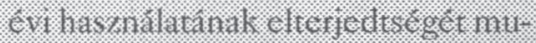

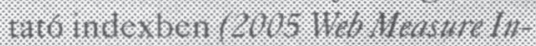

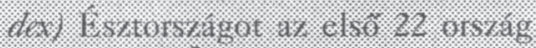

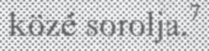

\footnotetext{
${ }^{3}$ Ezt a megállapítást alátámasztja az a tény, hogy mivel más országok is tanulhatnak Észtország tapasztalataiból (különösen az e-kormányzat terén), az Észt Köztársaság, az ENSZ Fejlesztési Programja (United Nations Development Program, UNDP) és a Nyitott Társadalom Intézet (Open Society Institute, OSI) információs programja közös kezdeményezéseként 2002-ben itt jött létre az elsố E-kormányzati Akadémia.

${ }^{4}$ Ezt a fogalmat például az Economist Intelligence Unit a következóképpen definiálja: „Valamely ország infrastruktúrájának felkészültsége, valamint az ország fogyasztóinak, üzleti vállalkozásainak és kormányzatának arra való alkalmassága, hogy az IK'T-t a saját hasznukra fel tudják használni.” Másutt is hasonló meghatározásokat alkalmaznak.

${ }^{5}$ A 2002. évi helyzetet részletesebben bemutató pillanatfelvételról lásd Krull 2003. A kép hasonló marad a késóbbi áttekintésekben is, lásd például Accompanying Document to the i2010 [...] 2007; Information Society Benchmarking Report [...] 2005.

${ }^{6}$ Economist Intelligence Unit 2006.

${ }^{7}$ UN Global E-government Readiness Report 2005, 88.

${ }^{8}$ Az észtországi esettanulmányt Kalvet és Aaviksoo jegyezte (2007).
} 
tehát fóleg íróasztali kutatáson alapul, bár a fent említett projektek során interjúkat is készítettünk szakértốk tucatjainak bevonásával. A szerző itt mond köszönetet valamennyi interjúalanyának. A szövegben esetleg benne maradt valamennyi pontatlanságért és hibáért természetesen a szerző felelős.

\section{Az IKT-használat általános indikátorai}

Az internethasználat, amely a legjobban jellemzi az információs társadalom fejlettségét, Észtországban gyorsan növekedett az évek során. A TNS EMOR felmérései azt jelzik, hogy 2007-ben a 15-74 éves korosztály 63 százaléka, illetve a 6-74 évesek 65 százaléka tartozik az internetfelhasználók közé (lásd 1. ábra).

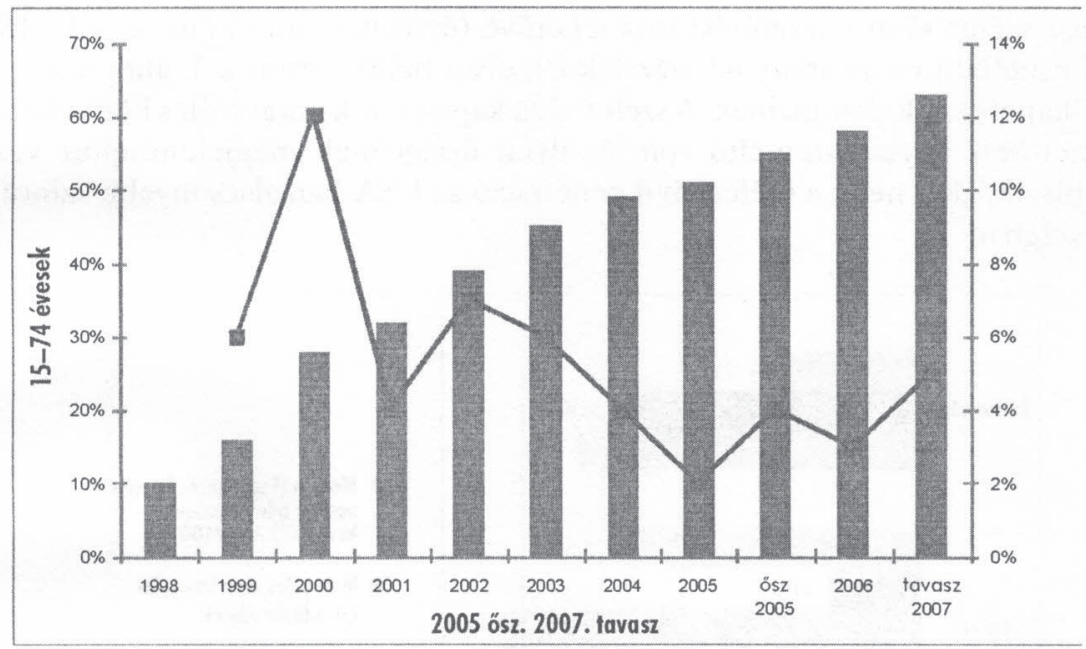

1. ábra

Az internetfelhasználók aránya Észtországban, 1998-2007

Forrás: TNS EMOR 1998-2007

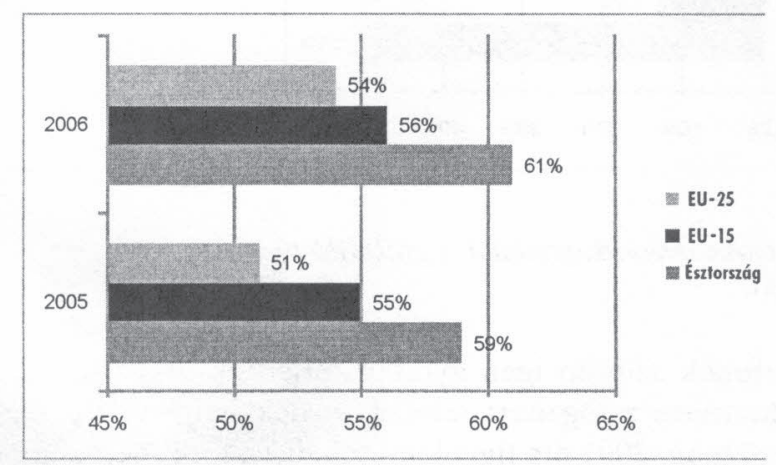

2. ábra

Azoknak a 16-74 év közötti személyeknek az arạnya, akik aะ utóbbi három hónap során használták az internetet

Forrás: Eurostat 2007 
Észtország az Eurostat kimutatásai szerint jobb teljesítményt nyújt az Európai Unió átlagánál: az internethasználók részaránya Észtországban kissé magasabb volt, mint az EU átlaga (2. ábra).

2006-ban Észtország lakosságának 46 százaléka használhatta az internetet otthonában, és az internetfelhasználók részaránya folyamatosan növekszik (2004-tól 2005-ig 32 százalékról 40 százalékra emelkedett). 2006-ban az EU-15 országokban ugyanez az indikátor 45 százalékos, az EU-25 esetében pedig 43 százalékos volt. Észtországban a második leggyakoribb felhasználási helyként a munkahelyet jelölték meg a megkérdezettek, az oktatási intézmények a harmadik helyen álltak. A nyilvános internethozzáférési pontokat 2005-ben és 2006-ban az emberek 2 százaléka vette igénybe, míg 2004-ben ez az arány még 6 százalékos volt. ${ }^{9}$

A háztartásokban meglevő internetkapcsolatok nagy (2006-ban 80 százalékos) többsége széles sávú hozzáférést tesz lehetôvé (összehasonlításként: az EU-15 és az EU-25 esetében ez az arány 62 százalékos), ezen belül - mint a 3. ábra mutatja - az ADSL-kapcsolatok dominálnak. A széles sávú kapcsolatok korai széles körú elterjedése meglehetősen figyelemreméltó volt, és ilyen újságcímek megjelenéséhez vezetett: „Akár hiszik, akár nem: a széles sávú penetráció az USA-ban alacsonyabb szintú, mint Észtországban."

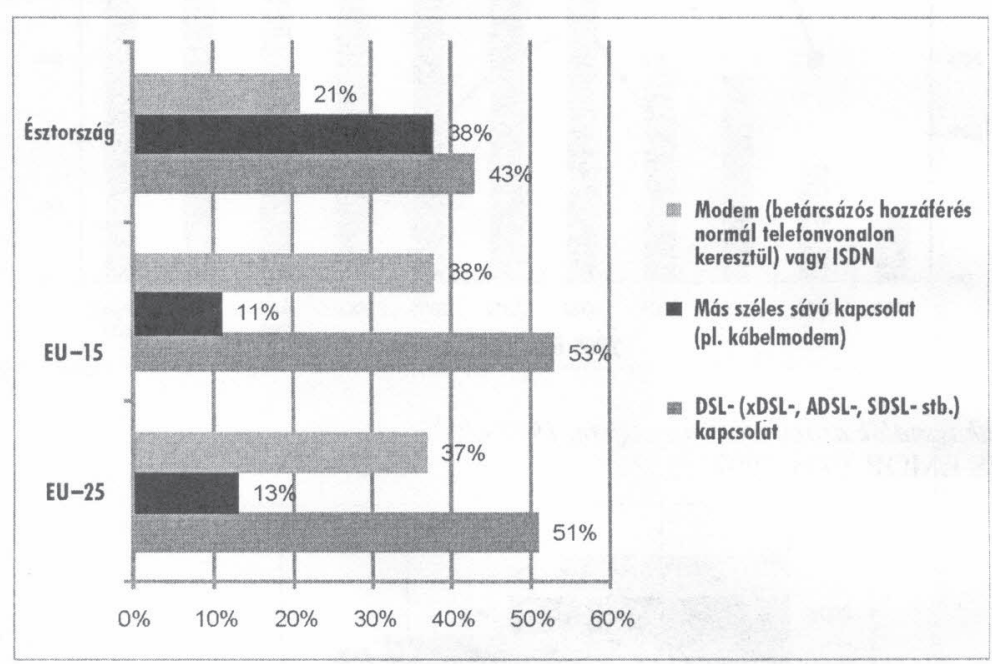

3. ábra

A háztartásokban meglevö internetkapcsolatok leggyakoribb típusai

Forrás: Eurostat 2007

A mobiltelefonok szintén igen gyorsan terjedtek el, és felhasználásuk jelentős mértékben csökkentette a rögzített telefonvonalak iránti igényeket: ez a tendencia 2000 óta figyelhető meg. 2001 óta figyelemre méltó mértékben szaporodnak az ADSL vonalak (lásd 4. ábra).

\footnotetext{
${ }^{9}$ Eurostat 2007.
} 


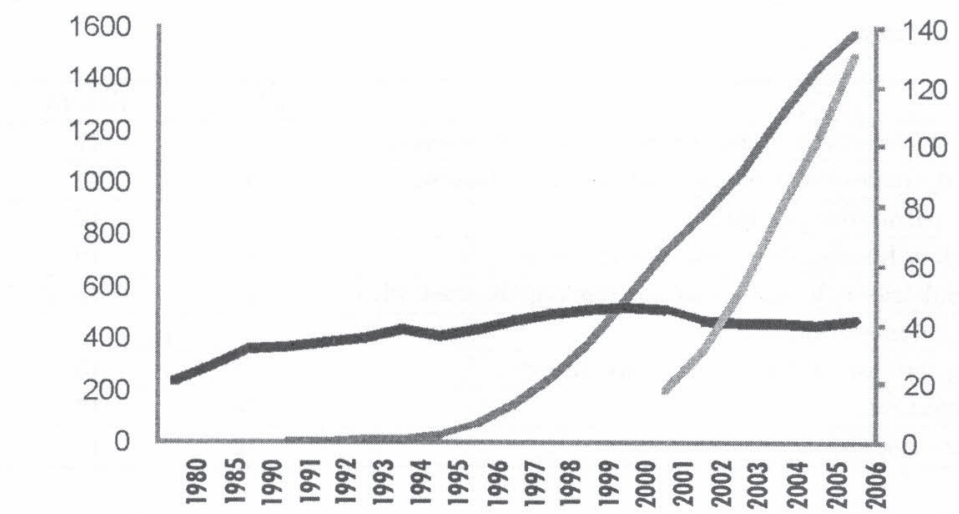

- Mobilhálózatok felhasználói

Föbb telefonvonalak

ADSL vonalak

4. ábra

A fóbb telefonvonalak, aะ ADSL vonalak és a mobilhálózatok felhasználói

Forrás: Az Észt Köztársàság Statisztikai Hivatala (2007)

Az EU-25 és az EU-15 országokhoz hasonlóan az internetet Észtországban is fốként elektronikus levelezésre és különféle árukkal és szolgáltatásokkal kapcsolatos információk keresésére használják. Az észtországi internetfelhasználás azonban különbözik az EU átlagos mintáitól abban a tekintetben, hogy a pénzügyi szolgáltatások (fóként az internetbankolás) és az online megjelenô újságok és hírmagazinok olvasása, illetve letöltése itt viszonylag népszerúbb. Az e-kormányzati szolgáltatásokat is széles körben használják. Ugyanakkor az internet kevésbé használatos oktatási kurzusokon való részvételre (és általában az elektronikus tanulásra), valamint az e-gazdaság körébe tartozó tevékenységek folytatására (lásd 1. táblázat).

1. táblázat

Az interneten folytatott tevékenységek százalékos megoszlása az egyéni felhasználók körében (2006)

\begin{tabular}{|l|c|c|c||}
\hline & EU-25 & EU-15 & Észtország \\
\hline Kommunikáció & 46 & 48 & 52 \\
\hline Formális oktatási tevékenységek (iskola, egyetem stb.) & 9 & 9 & 6 \\
\hline $\begin{array}{l}\text { Más oktatási kurzusok, különös tekintettel az elhelyezkedési le- } \\
\text { hetôségekre }\end{array}$ & 8 & 9 & 2 \\
\hline Továbbképzési kurzusok & 9 & 10 & 2 \\
\hline Hivatalos úrlapok letöltése & 14 & n. a. & 17 \\
\hline Információszerzés az állami hatóságok honlapjairól & 23 & n. a. & 27 \\
\hline Kitöltött ürlapok beküldése & 9 & n. a. & 17 \\
\hline $\begin{array}{l}\text { Egészségügyi információk keresése sérülésekkel, betegségekkel } \\
\text { vagy táplálkozási kérdésekkel kapcsolatban }\end{array}$ & 20 & 21 & 18 \\
\hline Pénzügyi szolgáltatások (internetbankolás, részvényvásárlás) & 22 & 24 & 48 \\
\hline Oktatás és képzés & 20 & 22 & 8 \\
\hline E-mail üzenetek küldése és fogadása & 44 & 46 & 49 \\
\hline Játékok és zene lejátszása, letöltése & 18 & 18 & 28 \\
\hline Hatóságokkal való interakciók & 26 & n. a. & 29 \\
\hline
\end{tabular}


1. táblázat (folytatás)

\begin{tabular}{|l|c|c|c||}
\hline & EU-25 & EU-15 & Észtország \\
\hline Utazással és szállással kapcsolatos szolgáltatások igénybevétele & 27 & 29 & 20 \\
\hline Árukra és szolgáltatásokra vonatkozó információk keresése & 43 & 46 & 44 \\
\hline Álláskeresés, pályázatok beküldése & 11 & 12 & 17 \\
\hline Online újságok és hírmagazinok olvasása, letöltése & 19 & 19 & 50 \\
\hline Más kommunikációs célú felhasználások (csevegófórumok stb.) & 18 & 18 & 21 \\
\hline Telefonálás, video-konferencia & 7 & 7 & 14 \\
\hline Áruk és szolgáltatások értékesítése (pl. árverések) & 9 & 10 & 3 \\
\hline Szoftverek letöltése & 16 & 17 & 21 \\
\hline Rádióhallgatás, televíziónézés & 12 & 12 & 17 \\
\hline
\end{tabular}

Forrás: Eurostat 2007

Azoknak a személyeknek az aránya, akik átlagosan hetenként legalább egyszer használják az internetet, a 2004. évi 45 százalékos szintról 2006-ban 56 százalékra emelkedett: ez valamelyest meghaladja az EU-15 és az EU-25 átlagát (49, illetve 47 százalék). Az internetet mindennap vagy majdnem mindennap használó személyek részaránya 2005-ben és 2006-ban egyaránt 40 százalékos volt. ${ }^{10}$

A vállalatok 92 százalékának van internet-hozzáférése (az EU-25 átlaga ebben a tekintetben szintén 92 százalék), fóként széles sávú összeköttetéssel (76 százalék). ${ }^{11} \mathrm{Az}$ internetkapcsolattal bíró vállalatok 79 százaléka tart fenn saját honlapot a hálózaton. ${ }^{12}$

2. táblázat

A vállalatok hálózati tevékenységeinek százalékos megoszlása $(2006)^{13}$

\begin{tabular}{|l|c|c|c|}
\hline & EU-25 & EU-15 & Észtország \\
\hline Ügyfélszolgálati tevékenységek & 33 & 36 & 36 \\
\hline Bank- és egyéb pénzügyi szolgáltatások & 74 & 74 & 90 \\
\hline Digitális áruk és szolgáltatások fogadása & 41 & 44 & 30 \\
\hline Az internet piacfigyelési célú használata (pl. árak) & 54 & 53 & 45 \\
\hline
\end{tabular}

Forrás: Eurostat 2007

\section{Politika és szabályozás}

Az információs társadalom és a tudásalapú gazdaság felépítésére irányuló eroófeszítések hosszú elớzményekre tekintenek vissza az észtországi politikai életben. Az első információs társadalmi stratégia „Észtország útja az információs társadalomhoz” címmel már 1994-ben elkészült. A stratégia kidolgozását nagymértékig ösztönözte az EU és az USA hasonló dokumentumainak megjelenése (Európában az 1993-ban kiadott White

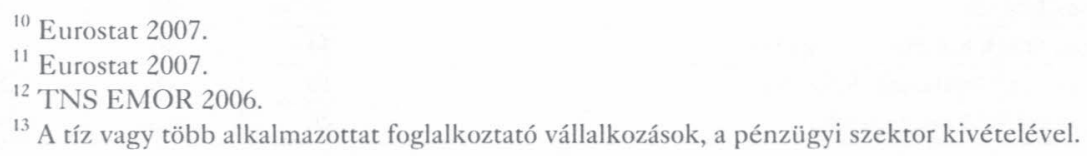


Paper on Growth, Competitiveness and Employment és az 1994-ben készült úgynevezett „Bangemann-jelentés”, illetve az USA-ban 1994-ben létrehozott Information Infrastructure Task Force jelentései), és tartalma nagyrészt az infrastruktúra fejlódését befolyásoló piaci fogyatékosságok felszámolására koncentrált. ${ }^{14}$

Az észt információs társadalmi politika legfóbb politikai dokumentumát, amely „Az észt információs társadalmi politika alapelvei” (Principles of Estonian Information Policy) címet viselte, 1998-ban hagyta jóvá a parlament. Az ebben rögzített stratégiai eszközök a következók: a törvényhozás korszerúsítése, a magánszektor fejlódésének támogatása, az állam és az állampolgárok közötti interakciók fejlesztése, valamint az információs társadalommal összefüggő problémák tudatosítása a társadalomban. Azóta számos akcióterv készült a politikai stratégia végrehajtására. A stratégiában lefektetett alapelvek szem elốtt tartásával információs politikai akcióterv kidolgozására került sor, amelyet a teendók idốzítése és a finanszírozási forrásokért, illetve a feladatok gyakorlati végrehajtásáért viselt felelôsség megoszlása tekintetében évente korszerúsítenek, valamennyi kormányhivatal konkrét javaslatainak figyelembevételével.

Az eredeti stratégia egy korszerúsített változatát (Principles of the Estonian Information Policy, 2004-2006) 2004-ben fogadta el a kormány. Ez megerôsítette az e-kormányzati szolgáltatások fejlesztésének prioritását, a következố fó célokat hangsúlyozva: e-szolgáltatások bevezetése valamennyi állami hivatalban, az igénybevételükhöz szükséges tájékoztatási és képzési tevékenységekkel együtt az egész társadalom számára; az IKT felhasználási szintjének legalább az EU átlagos szintjén tartása s ennek érdekében az észt gazdaság és társadalom általános hatékonyságának biztosítása; továbbá az ITszektor exportkapacitásának növelése. A 2004-2006. évi stratégia a fentiek mellett az alábbi kulcsfontosságú feladatokat emelte ki: I'T-megoldások kidolgozása az e-demokrácia kibốvítésére; az állami szektor hatékonyságának növelése; a digitális írástudás növelése elektronikus tanulás útján; az IKT-vel összefüggố kutatási és fejlesztési tevékenység bővítése, a magánszektor közremúködésének szorgalmazásával; országos IT-biztonsági központ létrehozása, kapcsolódási pontként az EU valamennyi intézményéhez; Észtország mint „e-állam” nemzetközi elismertségének fokozása; továbbá az IKT-eszközökhöz való hozzáférés megkönnyítése a hátrányos helyzetú társadalmi rétegek számára. Fố elveiket tekintve a dokumentumok meglehetôsen hasonlók egymáshoz, bár az újabbik konkrétabban határozza meg a célokat és az eszközöket, és az információs társadalom felépítését kapcsolatba hozza az oktatással, a kutatással és fejlesztéssel, a kultúrával, a gazdasággal stb. Hasonlóan az egész világon érvényesülő trendekhez, itt is világosabbá váltak az állam feladatai az információs társadalom fejlesztése terén. Az újabb stratégia kidolgozásakor figyelembe vették az Európai Unió eEurope és eEurope+ címú politikai dokumentumait is.

„Az észt információs társadalom fejlesztési terve, 2013” (Estonian Information Society Development Plan 2013) címú legújabb politikai program céljai átfogják a társadalmi, gazdasági és intézményi dimenziókat egyaránt. Ez a tervezet elóírja, hogy az információs társadalom fejlesztése során nem jöhetnek létre további egyenlốtlenségek és szakadékok, és az információs társadalomnak csökkentenie kell a meglevố szakadékokat. Ennek érdekében nagy hangsúly kerül az úgynevezett gazdasági és intézményi

\footnotetext{
${ }^{14}$ Kalvet 1997.
} 
„pillérek” szerepére. A legfontosabb célok között szerepel az IKT széles körú felhasználásának szorgalmazása, valamint több hozzáadott érték létrehozása az észt IT-szektorban, különös tekintettel az exportlehetôségekre. Az intézményi pillér tekintetében a fejlesztési terv annak biztosítását írja elő, hogy az állami szektor múködése állampolgár-központú, átlátható és hatékony legyen.

Egy másik igen fontos politikai terület is közvetlen kihatással van az információs társadalom kiépítésére: a kutatási, fejlesztési és innovációs $(\mathrm{K}+\mathrm{F}+\mathrm{I})$ politika potenciálisan közvetlenül befolyásolja az információs társadalom fejlődését. A K + F + I tevékenység irányításának stratégiáját Észtországban az „Észt kutatási és fejlesztési stratégia, 2002-2006" (Estonian Research and Development Strategy 2002-2006), majd azt követóen az „Észt kutatási, fejlesztési és innovációs stratégia, 2007-2013” (Estonian Research, Development and Innovation Strategy 2007-2013) címú dokumentumok fogalmazzák meg. Az ezekben felvázolt jövốkép és a kitúzött célok - a tudásalapú Észtország - megvalósításához mindkét stratégia a felhasználóbarát információs technológiák (az újabb stratégia esetében az IKT), a bioorvoslás (az újabb változatban a biotechnológiák) és az anyagtechnológiák szerepét emeli ki.

Míg valamennyi politikai párt egyetért abban a célban, hogy Észtországot sikeres információs, illetve tudásalapú társadalommá kell tenni, a politikai retorika és a tényleges akciótervek kapcsolatai tisztázatlanok. A célok eléréséhez még ma is döntô fontosságú a politikai támogatás, mivel bizonyos technológiai eszközök, például a digitális aláírási infrastruktúra (Public Key Infrastructure) és a digitális személyazonosító kártya (ID Gard), valamint bizonyos alkalmazások (például az elektronikus szavazás) bevezetéséhez megfelelố szabályozási környezetre van szükség, ám ezzel kapcsolatban időnként heves politikai vitákra kerül sor. ${ }^{15}$ Noha a tudásalapú Észtország megteremtése és az IKT használatának szorgalmazása kiemelkedő helyet foglal el minden politikai párt programjában, ez nincs alátámasztva pontosan meghatározott politikai eszközökkel. A 2002-2006. évi K + F + I stratégia alapján például egyes kulcsterületeken országos programok indultak, amelyek során konkrét terveket és intézkedéseket kellett kidolgozni a K + F + I tevékenység ösztönzésére a stratégiában kijelölt céloknak megfelelốen. Mindeddig azonban nem került sor a prioritások konkrét kijelölésére, és nem készültek részletesen kidolgozott megvalósítási tervek sem.

Mindent egybevetve, Észtország sok innovatív megoldást vezetett be az állami szektorban (amelyekkel tanulmányunk harmadik részében foglalkozunk), bár néha nehéz tisztán látni, hogy ezeket a projekteket a jóváhagyott politikai programokból és akciótervekból vezették-e le, vagy pedig egyébként is kialakultak volna, és maguknak a politikai törekvéseknek a megfogalmazására csupán post factum került sor. Az észt e-kormányzat fejlesztése igen pragmatikus szemlélettel valósult meg, és a stratégiák és a tényleges fejlesztési lépések inkább fordított ok-okozati kapcsolatban állnak egymással, vagyis inkább „a fejlődésból leszúrt stratégiáról”, mintsem „a stratégiából következó fejlốdésról" beszélhetünk.

Észtországot gyakran mutatják be olyan országként, ahol kedvezố törvényhozási környezet van az IKT felhasználásának terjedéséhez, és a legfontosabb törvényeket külsố nyomás nélkül hozzák meg, például az Európai Unió egészére érvényes törvény-

${ }^{15}$ Ezek áttekintését illetôen lásd Drechsler-Madise 2004. 
erejű előírások (acquis) tekintetében. A szabályozási keretek bizonyos esetekben valóban döntố fontosságúak. A közérdekú információkra vonatkozó törvény például 2001 januárjában lépett hatályba. Ez a törvény fontos rendelkezéseket tartalmaz az elektronikusan tárolt adatokhoz való hozzáférésre, illetve az adatok közzétételére vonatkozóan: ilyen intézkedés többek többek között a hálózati honlapok fenntartásának előírása, az információk „naprakész, pontos és nem félrevezetô” jellegének biztosítására való kötelezettség, az e-mail üzenetekben érkező kérelmek hivatalos információkérésként való kezelése stb. A hálózati honlapokon közzétett információk igen széles körre terjednek ki, és az állami szférán belül változások következnek be az információkezelés gyakorlatában, hozzájárulva a „jó kormányzat” kialakulásához Észtországban.

A 2000. március 8-án elfogadott elektronikus aláirási törvény megteremti a szükséges feltételeket a digitális aláírás használatához, valamint a bizonylatolási és határidôhöz kötött szolgáltatások felügyeleti eljárásainak alkalmazásához. A digitális aláirás ugyanolyan jogi következményekkel jár, mint a saját kezú aláírás.

A parlamenti választásokra vonatkozó törvény szerint a digitális aláíási jogosultságot szerzett szavazók az Országos Választási Bizottság honlapján is leadhatják szavazatukat, de csak a szavazás elốtti napokban (a választás elótti hatodik naptól a negyedik napig).

Az állam részéról az észt információs társadalom erôteljes fejlődésének biztosítása érdekében tett legnagyobb hatású lépések összefüggnek a külföldi partnerek korai bevonásával az észtországi vezetékes kommunikációs hálózatok fejlesztésébe, ${ }^{16}$ majd késóbb az észt távközlési piac liberalizálásába is. Noha az Észt Köztársaság kormánya és az Észt Telefontársaság között 1992-ben megkötött koncessziós egyezmény 2001-ig kizárólagos jogokat biztosított a vállalat számára a vezetékes telefonszolgáltatások nyújtására, ${ }^{17}$ a vezeték nélküli távközlési szolgáltatások (például a mobiltelefónia és az adatközlés, a személyi hívó készülékekre épülő́ szolgáltatások, a múholdas kommunikáció és a hozzáadott értéket tartalmazó szolgáltatások) terén a szabad verseny érvényesült. Bár a hálózatok létesítéséhez és múködtetéséhez állami engedélyre van szükség, a piac általános liberalizálása révén Észtország a közép- és kelet-európai országok sorában az elsốk között nyitotta meg a verseny elótt távközlési piacának valamennyi szegmentumát.

\section{E-kormányzał}

Az online elérhetô közszolgáltatások tekintetében Észtország a maga kifinomult rendszerével fejlettnek számít. Az ország nem csupán elsố helyen áll az Európai Unió új tagállamai között, hanem az EU-15 országok többségénél is jobb eredményeket mutat fel (lásd 5. ábra). A 2004. évi helyzethez képest figyelemre méltó fejlődési eredményekról lehet beszámolni. ${ }^{18}$

${ }^{16}$ Bôvebben lásd Högselius 2005, 79-92.

${ }^{17}$ A koncessziós egyezmény az országos és nemzetközi vezetékes telefon-, telex-és távirati szolgáltatásokra, hálózatok létesítésére és az azok közötti kapesolatok megteremtésére korlátozódott.

${ }^{18}$ Míg 2004 októberében Észtország még csak a nyolcadik helyen állt az európai országok között, 2006-ban már a harmadik helyre került. 


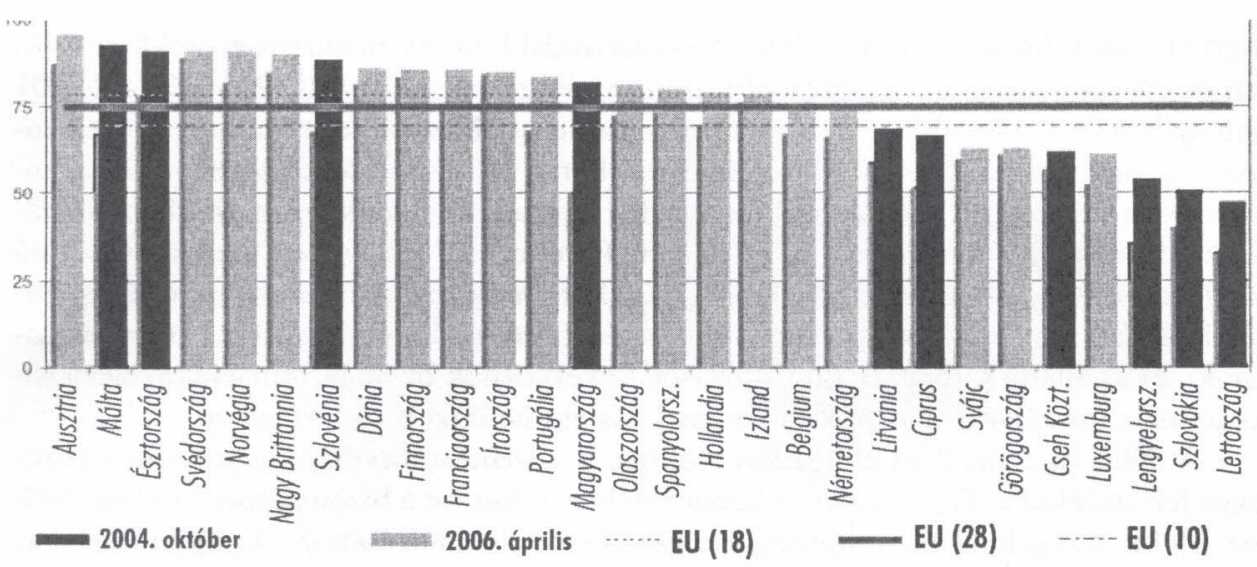

5. ábra

As online elérhetố közszolgáltatások kiépittettsége, 2006

Forrás: Online Availability of Public Services... 2006, 8.

A teljes körú elektronikus ügyintézést lehetôvé tevô szolgáltatások aránya szintén igen magas: a szolgáltatások több mint 75 százaléka vehető igénybe teljes mértékben elektronikus úton, ami jelentősen meghaladja az EU-25 átlagos szintjét (lásd 6. ábra). Észtországban már alapszinten is minden közszolgáltatás tartalmaz e-szolgáltatási komponenst. Valamennyi állami és helyi önkormányzati hivatal, törvényesen elismert jogi személy és közjogi funkciót ellátó magánszemély köteles elfogadni a digitális aláírással ellátott dokumentumokat. 2002 óta összesen több mint hatvanezer felhasználó részéról több mint 2,6 millió alkalommal került sor digitális aláírás alkalmazására különféle szerződések, folyamodványok, kereskedelmi tranzakciós megrendelések stb. aláírásakor. ${ }^{19}$

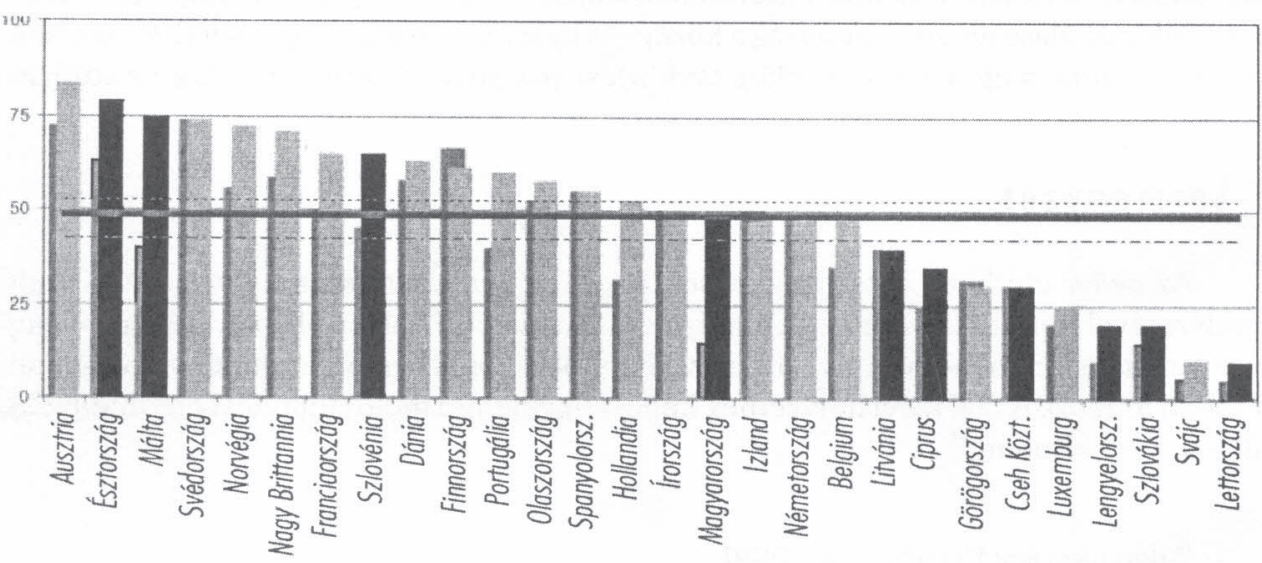

6. ábra

A teljes mértékben online elérhetö közszolgáltatások százalékos aránya, 2006

Forrás: Online Availability of Public Services... 2006, 9. 
Észtország lett az elsố ország a világon, ahol az állampolgárok az ország egész területén az interneten keresztül adhatták le szavazatukat politikai választásokon, nevezetesen a helyi önkormányzatok 2005. október 16-án történt megválasztása alkalmából. A digitális személyazonosító kártyákra alapozott rendszer lehetővé tette az állampolgárok számára, hogy szavazatukat elektronikus aláírással adják le az interneten keresztül: az így beérkezett szavazatok száma a helyi választások során összesen 9287 volt, ami az összes leadott szavazatok 1,85 százalékát tette ki. ${ }^{20} \mathrm{Az}$ ilyen rendkívül innovatív szolgáltatások mellett van néhány további, hagyományosabb szolgáltatás is, amelyeket az állampolgárok kiemelkedôen széles köre vesz igénybe. Észtország egyike pl. a világ vezetố országainak az adóbevallások és vámnyilatkozatok elektronikus úton történô benyújtásának népszerúsége tekintetében is. 2006-ban magánszemélyek összesen 532 ezer adóbevallást nyújtottak be az észt adóhatósághoz, s ezeknek a 82 százaléka az elektronikus adóbevallási rendszeren keresztül érkezett be (összehasonlításként: ez az arány 2004-ben 59, 2005-ben pedig 75 százalékos volt). ${ }^{21}$

Az e-kormányzati szolgáltatások kiépítése Észtországban az úgynevezett $X$-Road projekt keretében ment végbe. Az $X$-Road egységes interfészek alkalmazását biztosítja különféle adatbázisokhoz, és olyan felületet nyújt az adatok cseréjéhez, amely lehetôvé teszi mind a hivatalok, mind a jogi és természetes személyek számára, hogy saját hatáskörük korlátai között feldolgozzák az országos adatbázisból az interneten keresztül hozzájuk érkező adatokat. ${ }^{22}$

Az észt kereskedelmi bankok és egyes magánvállalatok adatfelhasználóként szintén rákapcsolódnak az X-Road rendszerre. Az Észtországban bevezetett digitális személyazonosító kártyák és az általuk nyújtott elektronikus hitelesítési és felhatalmazási lehetôségek központi szerepet játszanak az e-szolgáltatásokban. E nélkül az infrastruktúra nélkül Észtországban több innovatív közszolgáltatás (például az e-szavazás) nem volna lehetséges. A kártya - amellett, hogy fizikai személyazonossági dokumentumként szolgál - fejlett elektronikus funkciókat tölt be, lehetővé téve dokumentumok biztonságos hitelesítését a jogilag kötelezô erejú digitális aláírás révén. Az ebbe beépített elektronikus csip (melynek leolvasásához intelligens kártyaolvasó készülékre van szükség) tartalmazza a személyes adatokat, valamint a hitelesítéshez és a digitális aláíráshoz szükséges biztosítékokat. ${ }^{23}$

Az állami intézményeknél és hivataloknál használatos internetkapcsolatok jelenlegi fejlettségének eléréséhez hozzájárult számos jelentôsebb országos projekt is. Ezek a következók voltak: a PeaTee gerinchálózat (EEBone), amely az állami intézmények közötti adatkommunikáció széles sávú hálózataként szolgál; ${ }^{24}$ a KülaTee („,falusi út”) elnevezésú célprogram a PeaTee kiegészítő projektjeként, adatkommunikációs szolgáltatások biztosítására a helyi önkormányzati hivatalok, iskolák és könyvtárak számára; ${ }^{25}$

\footnotetext{
${ }^{19}$ Részletesebb áttekintéshez lásd Certification Centre 2007.

${ }^{20}$ Részletesebben lásd The National Election Committee 2006.

${ }^{21}$ Estonian Tax and Customs Board 2007, 41.

${ }^{22}$ Lásd http://www.ria.ee/27309

${ }^{23}$ Lásd http://www.id.ee

${ }^{24}$ Lásd http://www.ria.ee/27315

${ }^{25}$ Lásd http://www.ria.ee/27426
} 
valamint az Észt Oktatási és Kutatási Hálózat (EENet) a tudomány, az oktatás és a kultúra számítógépes hálózatainak múködtetésére, koordinálására és fejlesztésére. ${ }^{26}$

Az „Információs társadalom az észt helyi önkormányzatokban” címú, 2006-ban végzett felmérés szerint, amelyben a megkérdezett 227 helyi hatóság közül 115 önkormányzat válaszolt a kérdốíven feltett kérdésekre, a helyi önkormányzatok helyzete mind a hardver, mind a szoftver tekintetében szintén jónak mondható. A helyi önkormányzatok digitális lehetôségeinek feltérképezése során alkalmazott BEGIX-mutatók ${ }^{27}$ azonban - 59 beérkezett válasz alapján - a helyi önkormányzatok különböző fejlettségi szintjét tükrözték. Egyes esetekben igen jó helyzettel találkozunk, de vannak lemaradók is. A helyi önkormányzatok saját értékelése szerint az IKT felhasználása nagymértékben hozzájárul a hatékonysághoz és az átláthatósághoz, míg más olyan fontos dimenziókban, mint például az általános társadalmi hasznosság, a politikai részvétel és a változásmenedzsment, nem ér el olyan jó eredményeket.

Az internetalapú közszolgáltatások népszerúségén túlmenốen Észtország jó hírnévre tett szert a hozzáadott értéket tartalmazó mobilszolgáltatások (mServices) terén is. Észtország volt az első ország a világon, ahol kereskedelmileg hasznosították a mobil helyzetmeghatározást, és egyike az elsốknek, ahol a vészhelyzeti sürgôsségi hívásokat mobil helyzetmeghatározó rendszerrel kapcsolták össze, amely meg tudja határozni minden egyes hívás eredetét. Valamennyi észt mobilhálózat kliensei már 2000 óta mobiltelefonjukon keresztül fizethetik a parkolási díjakat. Az m-szolgáltatások fejlesztésére különösen Tartu városában fordítanak nagy figyelmet. ${ }^{28}$

Az e-szolgáltatások terén elért általános kiválóság sokévi fejlesztési munka eredménye, és bizonyára nagyrészt a következô feltételek együttes fennállásának köszönhető. Először is, 1993 és 2000 között stabil és megfelelő mértékú anyagi fedezet állt rendelkezésre az állami I'T-kiadásokhoz, amelyek - a bérköltségeket leszámítva - a teljes állami költségvetés körülbelül 1 százalékát tették ki. ${ }^{29}$ Másodszor: az állami szektor IK'T-struktúrájának fejlesztése Észtországban igen korán megkezdôdött, és mindmáig sikeresnek mondható. A köztisztviselók többsége, akiknek a mindennapi munkájához szükségük van a számítógépre, megfelelően el vannak látva ezekkel. ${ }^{30} 2005$-ben a központi kormányzati szervek számítógépeinek 99 százaléka rácsatlakozott (legnagyobbrészt széles sávú kapcsolattal) az internetre. Ennél is fontosabb, hogy az állami szektor információs rendszereinek fejlesztése lelkes és a jövốre tekintố köztisztviselók kezében van. Igen sok külső szakértő is közremúködik a feladatok megoldásában, különösen az alábbiakban ismertetendő projektek keretei között, amelyek kitûnố alapot teremtettek az e-szolgáltatások megvalósításához Észtországban.

\footnotetext{
${ }^{26}$ Lásd http://www.eenet.ee

${ }^{27}$ Balanced E-Government Index: az e-kormányzati szolgáltatások önértékelésére kidolgozott eszköz. Lásd www.begix.net

${ }^{28}$ Rannu-Semevsky 2005.

${ }^{29}$ IT in Public Administration of Estonia 1994-2005, a szerző számításai.

${ }^{30}$ A központi apparátusok adminisztratív személyzetének 34,8 százaléka már 1995-ben el volt látva a munkahelyén üzembe helyezett számítógépekkel, és 1998-ban a számítógépes munkahelyek iránti igények 89 százalékát sikerült kielégíteni. Lásd Information Technology Means... 2005.
} 
Fontos megjegyezni továbbá, hogy a központi információs rendszerek és alkalmazások egy részét technokraták fejlesztették ki erre vonatkozó politikai előírások nélkül. A kormányzati honlapok létrehozása például nagyrészt a civilszervezetként múködő Nyílt Észtország Alapítvány (Open Estonia Foundation) érdeme, és a köztisztviselók nagymértékben támaszkodhattak a civil szektorban már korábban létrejött honlapokra (ilyen például az észtországi törvények és különféle hivatalos úrlapok online, teljes mértékben nyilvánosan hozzáférhető adatbázisa), amelyeket késôbb átvett az állami szektor.

\section{Az információs társadalom és a gazdaság}

Noha a szovjet korszakban Észtországban is túliparosítás ment végbe, az ország gazdasági szerkezete viszonylag kedvezó volt az új gazdasági szerkezet kialakításához, vagyis az ipar jelentôs része a magasabb hozzáadott értéket termelő ágazatokra orientálódott, amelyek ki tudták használni a jól képzett munkaerốt, és a tömegtermelésre berendezkedett, elavult iparágak viszonylag kisebb szerephez jutottak a gazdaságban különösen más szovjet köztársaságokhoz képest. ${ }^{31}$ A függetlenség 1991. évi visszanyerése óta az ország eróteljesen törekszik a Nyugattal való integrációra a szabad piacgazdaság keretei között.

A technológiatranszfer, a menedzseri készségek és a hatékonyabb piaci verseny elôsegítése érdekében Észtországban nagymértékú privatizáció ment végbe: a legtöbb vállalatot már 1995-ben privatizálták. A privatizáció egyike volt a fó tényezóknek, amelyek elősegítették a külföldi befektetési tóke (foreign direct investment, FDI) beáramlását Észtországba. Az FDI döntő szerepet játszik az észtországi magánszektor fejlôdésében (a közvetlen külföldi befektetések ágazati megoszlását a 7. ábra mutatja). Az FDI részaránya a bruttó fix tókevagyon ${ }^{32}$ képződésében - bár az 1990-es években ingadozásokat mutatott - 1993-ban pl. 40,8 százalékos, 1998-ban pedig 37,9 százalékos szintet ért el. ${ }^{33}$ A külföldi közvetlen tókebefektetések legnagyobb része a fejlett technológiákban élenjáró szomszédos Finnországból és Svédországból érkezik.

Az észt információs társadalom fejlódésének egyik zászlóshajója a távközlési szektor. A stratégiai partnerek bevonására irányuló kritikus fontosságú döntések számottevő befektetésekhez vezettek a távközlési szektorban, és jelentôsen hozzájárultak a távközlési hálózatok korszerúsítéséhez (lásd 7. ábra). ${ }^{34} \mathrm{Az}$ adatkommunikációs piacon erốs verseny folyik. A széles sávú adatátviteli technológiák köre magában foglalja az ADSLés kábelmodemes, WiMax-, CDMA- és WiFi-kapcsolatokat, amelyek 1109 „forróponton" érhetók el Észtország területén. ${ }^{35}$

${ }^{31}$ Lásd például Hansen-Sorsa 1994.

${ }^{32}$ A vállalatok által a belföldi gazdaságban eszközölt új befektetések mértéke fix tókevagyonban.

${ }^{33}$ OECD 2001, 10.

${ }^{34}$ Noha a távközlési szektorra vonatkozóan nem állnak rendelkezésre részletes adatok, a vállalatok évi beszámolójelentései nagy volumenú befektetésekról tanúskodnak. Az Eesti Telekom például 2000-ben 88 millió eurót fektetett be a vezetékes és mobiltávközlés területén (Eesti Telekom 2001, 16).

${ }^{35}$ www.wifi.ee 


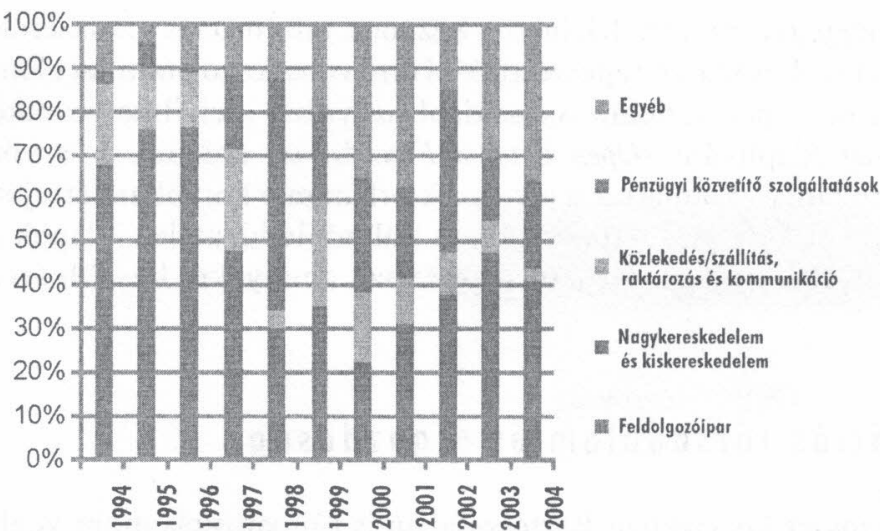

7. ábra

Közvetlen kiilföldi befektetések, tevékenységi teriiletek szerint

Forrás: Észtország bankja, 2007

Az észt IKT-piacon a távközlési hálózati szolgáltatások játszanak domináns szerepet. A legnagyobb észt vállalatok rangsorában - a kereskedelmi forgalom mércéjével mérve - a legnagyobb mobilkommunikációs szolgáltató, az EMT a hetedik helyen áll, az Elion (a korábbi ETC) pedig a tizenegyedik helyet foglalja el. A két további fő szolgáltató ugyanebben a rangsorban a harmincegyedik és a harminckettedik helyezett (2005. évi adatok). Ezeknek a vállalatoknak a profitrése 20 százalék körül van, bár az EMT 2005-ben elérte a kiemelkedố 30 százalékos haszonkulcsot is, ${ }^{36}$ amely bốséges pénzügyi forrásokkal szolgál ezeknek a vállalatoknak a további befektetésekhez és fejlesztési projektekhez, valamint az információs társadalom építésével összefüggó különböző kezdeményezésekben való közremúködéséhez Észtországban.

Az elsố bankokat Észtországban 1988-ban alapították meg, és fejlódésükhöz - a távközlési szektorhoz hasonlóan - nagymértékben hozzájárultak a közvetlen külföldi befektetések (lásd 7. ábra). 1995 végén az észt bankok részvénytókéjének 35 százaléka külföldi kézben volt. 1998-ban két nagy svéd bank, a Swedbank és a SEB többségi tulajdont szerzett a Hansapank, illetve az Eesti Ühispank részvénypakettjében.

Bizonyos mértékig rendkívülinek tekinthető, hogy az elektronikus bankolás és az internetbankolás milyen gyorsan terjedt el Észtországban. A Hansapank 1993-ban indította meg első, Telehansa elnevezésű elektronikus banki szolgáltatását. Az internetes bankszolgáltatásokat Észtországban először az Eesti Forekspank és az Eesti Hoiupank vezette be 1966-ban. ${ }^{37}$ Még ennél is kiemelkedóbb eredménynek tekinthetô, hogy míg a világ elsố internetes bankszolgáltatásai 1995-ben indultak meg, és 1996 végéig körülbelül húsz ilyen szolgáltatás jött létre, ezek közül három Észtországban múködött. ${ }^{38}$

Az 1990-es évek elején Észtországban még hiányzott a nagyszabású banki információs rendszereket kiszolgáló és azok továbbfejlesztését segítố erôs szoftveripar. Ez a

\footnotetext{
${ }^{36}$ A vállalatok éves beszámoló jelentése alapján, a szerző számítása.

${ }^{37} \mathrm{Az}$ internetbankolás történetét illetôen lásd Kerem 2003.

${ }^{38}$ Alec 2004. Lásd továbbá Centeno 2004.
} 
hiányosság viszont arra késztette az Észtországban múködő bankokat, hogy kifejlesszék ezen a téren a saját kapacitásaikat. Az egyik bank esettanulmánya azonban azt állítja, hogy a vállalatnál az internetbankolás kialakulása inkább a lelkes alkalmazottak munkájának, mintsem a rendszeres $\mathrm{K}+\mathrm{F}$ tevékenységnek vagy a felsố vezetóktól eredố irányításnak az eredménye. A programozók éjjel-nappal a saját kezdeményezéseik alapján fejlesztették az internetes bankszolgáltatásokat. ${ }^{39} \mathrm{~A}$ bankok belsố kapacitásának kifejlódése következtében olyan helyzet alakult ki, amelyben a bankok lettek a szoftveripar „informális” vezetối Észtországban. Ténylegesen az észt bankrendszer szabta meg a követelményeket más vállalatok e-szolgáltatásaihoz is mind az állami, mind a magánszektorban. A bankok szolgáltatják továbbá mind a mai napig a magán- és az állami szektor e-szolgáltatásainak igénybevételéhez szükséges hitelesítési mechanizmusokat is.

Számos észt szoftvervállalat is világszerte ismertté vált. Ezek közé tartozik a Skype, amelyben az észt programozók végezték el a fóbb kódok megírását a ma nemzetközi szinten népszerú VoIP-alkalmazáshoz, továbbá a Playtech, a világ legnagyobb nyilvános online kereskedelmet lebonyolító játékszoftver-előállítója is. A térképkiadóként indult Regio vállalatból fejlődött ki a GIS szoftver- és mobilalkalmazás-fejlesztő vállalat. Észtországban igen sok m-szolgáltatás fejlódött ki. ${ }^{40}$ A személyazonosítás céljára az EMT által a közelmúltban kibocsátott digitális aláírás és „mobil-ID” további egyedülálló szolgáltatásokat jelent.

Az észt IK'T-szektorban körülbelül 500 aktív vállalat múködik, amelyek együttesen 1,1 milliárd eurónyi forgalmat bonyolítanak le évente, és 8600 embert foglalkoztatnak. ${ }^{41}$ A szektor meglehetốsen konszolidáltnak tekinthetố, a legnagyobb száz vállalat 90 százalékos részesedést tudhat magáénak a piacon (lásd 3. táblázat).

3. táblázat

Az észt IKT-piac, 2005

\begin{tabular}{|c|c|c||}
\hline Éves forgalom, millió euró & A vállalatok száma & Piaci részesedés \\
\hline 6,4 fölött & 24 & $72 \%$ \\
\hline $3,2-6,4$ & 19 & $8 \%$ \\
\hline $1,3-3,2$ & 47 & $8 \%$ \\
\hline $0,6-1,3$ & 57 & $4 \%$ \\
\hline $0,06-0,6$ & 325 & $7 \%$ \\
\hline 0,06 alatt & 168 & $1 \%$ \\
\hline
\end{tabular}

Forrás: Klaamann 2007

Noha néhány évvel ezelôtt elvégezték az észt IK'T-klaszter feltérképezését és a hozzá tartozó innovációs rendszer elemzését (lásd 8. ábra), a 2002. évi adatokból levont fóbb következtetések is mindmáig érvényesnek túnnek. A kormányzati struktúrák helyreállítása, a modern távközlés és a magánszektorban múködő bankrendszer, valamint a nagy- és kiskereskedelem és más tudásintenzív üzleti szolgáltatások gyors fejlő-

${ }^{39}$ Kalvet 2006, 81-83.

${ }^{40}$ A létrehozott m-szolgáltatások és az ezekhez kapcsolódó tényezók áttekintéséhez, beleértve a mobilparkolás, a mobil-menetjegyvásárlás és a mobilkereskedelem kérdéseit, lásd Rannu 2003.

${ }^{41} 640$ vállalat 2005. évi jelentései alapján becsült adat. 
dése szintén hozzájárult az észt IKT-klaszter kialakulásához. Ezt a megállapítást alátámasztani látszanak más országok adatai is. Egy 42 amerikai iparágra kiterjedô vizsgálatból a kutatók azt a következtetést vonták le, hogy a nagykereskedelem, a pénzügyi szektor és az üzleti szolgáltatások alkotják azokat a területeket, ahol a legnagyobb ITbefektetések történnek, és amelyek a legtöbb pozitív externáliát tudják felmutatni. Bár az észt IKT-iparágakban is mindenütt elófordul az IKT innovatív felhasználása, azoknak a vállalatoknak a részaránya, amelyek belsô, illetve külső üzleti folyamataikban intenzíven alkalmazzák az IKT-eszközöket, Észtországban alacsonyabb az EU átlagánál. ${ }^{42}$
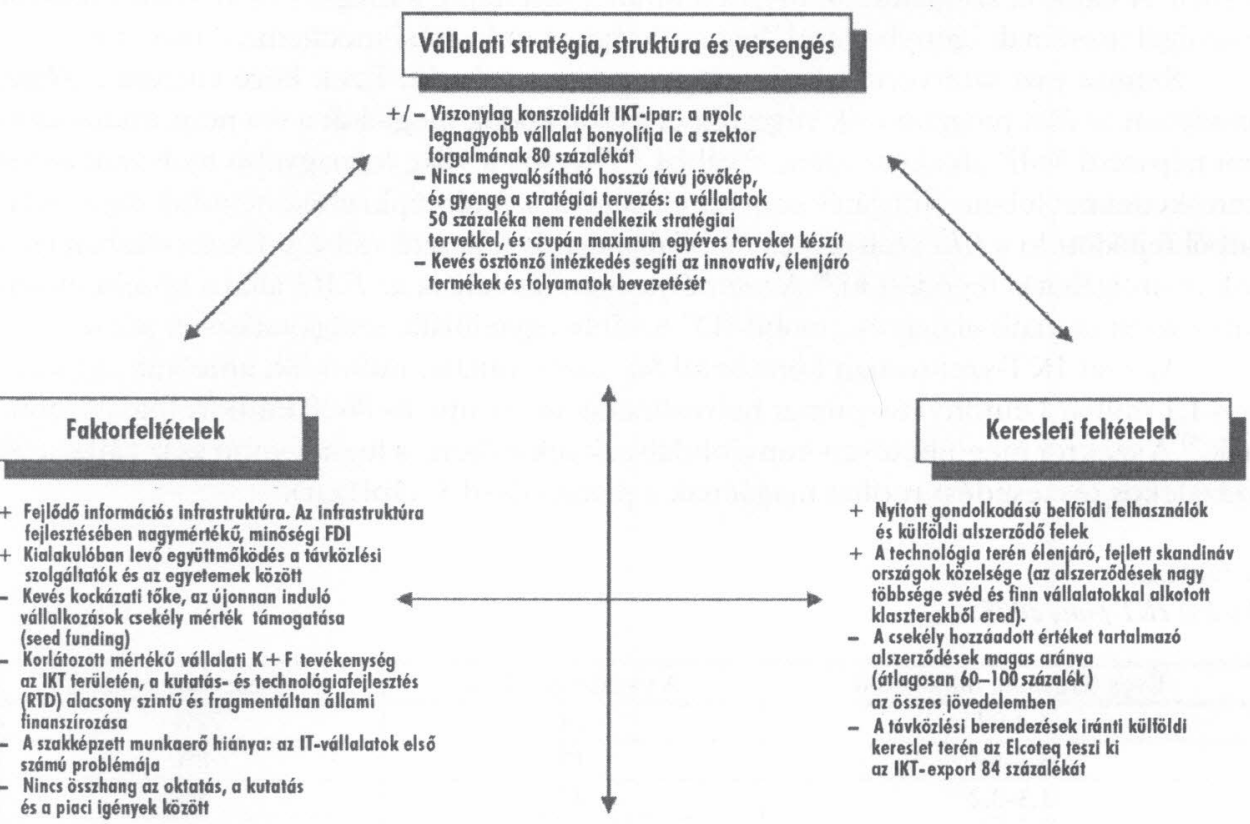

+ Fejlödõ információs infrastruktúra. Az infrastruktúr feilesstésében nagymértékü, minöségi FDI

+ Kialakulóban levố együttmốködés a távkörlés

szolgáliatók és az egyełemek között

Kevés kockázati tốke, ar újonnan induló vállalkozások csekély mérték támogatása (seed funding)

- Korlátozott mértékũ vállalati $K+F$ tevékenység az IKT területén, a kutatás- és technológiafeilesztés (RTD) alaesony szintú és fragmentáltan állam

- A szakképzett munkaerổ hiánya: az IT-vállalatok elsô

számú problémája

- Nincs ôsszhang az okfatás, a kutatás

és a piaci igények kōzöłt
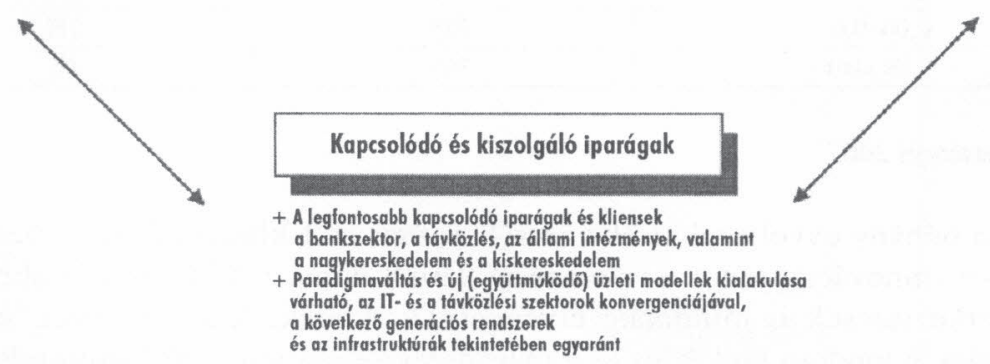

8. ábra

Az észt IKT-klaszter: a Porter-gyémánt

Forrás: Kalvet et al. 2002, 15

${ }^{42}$ Accompanying Document to... 2007, 26. 
Az IKT és általában az elektronikai iparágak területén szoros kapcsolatok állnak fenn Észtország és Finnország között: ez vonatkozik többek között az exportpiacokra és a tulajdonviszonyokra is, amiból azt a következtetést lehet levonni, hogy az észt IKT-szektor ténylegesen részét képezi a nagy északi IK'T-ipari klaszternek, amelyben alacsonyabb hozzáadott értékú tevékenységek folynak. ${ }^{43} \mathrm{Az}$ a tény, hogy az egyik szomszédos országban virágzó IKT-ipari tevékenység egyike az IKT körébe tartozó elektronikai termelés húzóeróinek Európában, ${ }^{44}$ minden bizonnyal kifejt olyan megtermékenyítố hatásokat, amelyek lehetốvé teszik Észtország számára is, hogy belépjen a globális termelési hálózatokba. Mindazonáltal, ha szemügyre vesszük az észt gazdaság és különösen az export hozzáadottérték-struktúráját, ${ }^{45}$ világossá válik, hogy az IKT-ipar szerepe a feldolgozóipar más ágazataihoz képest viszonylag kicsiny. Nincs továbbá meggyốzó empirikus bizonyíték arra a széles körben elterjedt nézetre, hogy az észt IKT-ipar az alacsony hozzáadott értéket produkáló gyártási tevékenységtól elmozdulóbban van a magasabb hozzáadott értéket termelő alágazatok felé.

\section{Oktatás és $K+F$}

Az informatikai oktatás Észtországban a két állami egyetemen - a Tallinni Mûszaki Egyetemen és a Tartui Egyetemen -, valamint a magánintézményként múködő Észt Informatikai Fốiskolán (Estonian Information Technology College) összpontosul. Az elsố két intézmény fóként a tudományos képzés, az utóbbi pedig a gyakorlati alkalmazásokra orientált felsôoktatás terén játszik fontos szerepet. Gyakorlati orientációjú képzést több más magánkézben levő felsőoktatási intézmény is nyújt. ${ }^{46}$

A különbözố alacsonyabb szintû́ képesítéseket nyújtó kurzusokon informatikai tanulmányokat végzố hallgatók száma 2006-ban összesen 1336 fő volt. Az első egyetemi fokozathoz vezetố kurzusokon 1905, a mesterképzésben pedig 683 hallgató vett részt, és 128 -an végeztek doktori tanulmányokat. ${ }^{47} \mathrm{Az}$ egyetemi diplomát szerzett hallgatók alacsony száma (2006-ban 5 PhD-fokozat, 60 mesterfokozatú és 285 alapképzési diploma) vitákat váltott ki Észtországban arról, hogy az IK'T-szakemberek aggasztó hiánya gátolhatja a további fejlődést. Ezeket a problémákat csak súlyosbítja, hogy a népesség csökkenése valószínúleg számottevő hatást fog gyakorolni az észt oktatási rendszer egészére: az oktatási intézmények potenciális hallgatóinak száma 2007 után csökkenni kezd.

Noha az informatikai oktatás eddig fóként a magánszektorban végrehajtott fejlesztési programokat támogatta, jelenleg világos, hogy a tantervek módosításra szorulnak: a vállalatok elégedetlensége a fiatal szakemberekkel és az ezzel kapcsolatos tantervi gondok abból adódnak, hogy a tananyagok nem kellő mértékben irányulnak a

${ }^{43}$ Kalvet 2002.

${ }^{44}$ Koski et al. 2002.

${ }^{45}$ Kaasik 2003.

${ }^{46}$ Az IKT-szektorhoz kapcsolódó oktatási és kutatási rendszer, illetve szakmai oktatás részletesebb áttekintéséhez lásd Kattel és Kalvet 2006, 4. és 5. fejezet.

${ }^{47}$ Az Észt Köztársaság Statisztikai Hivatala. 
gyakorlati problémákra, és ez okozza a megfelelő szakértelem és készségek hiányát a diákoknál. ${ }^{48}$

Szakmai körökben jól ismert a közoktatás szintjén folyó informatikai oktatás fejlesztése érdekében tett egyik észtországi kezdeményezés, nevezetesen az úgynevezett „Tigrisugrás Alapítvány”, amelyet 1997-ben hoztak létre a közoktatási intézmények IK'T-berendezésekkel való ellátásának támogatására. Miközben az alapítvány erôs politikai támogatást élvezett, és kétségkívül sikerült növelnie az IKT-penetrációt az iskolában, egyes mélyen meghúzódó problémák megoldatlanok maradtak. Pl. a Quangos nevú kvázifüggetlen nem kormányzati szervezet jelentôs szerepet kapott Észtországban az informatikai képzés és az e-learning területén. Ez azonban olyan helyzet kialakulásához vezetett, amelyben a kormányzat lemondott a fejlesztési programok irányításáról, és ezekhez nem nyújt a szükségleteknek megfelelő jogi és pénzügyi támogatást. ${ }^{49}$

A tudományos eredmények és a $\mathrm{K}+\mathrm{F}$ tevékenység tekintetében figyelembe kell venni, hogy más korábbi szovjet köztársaságokhoz viszonyítva Észtország meglehetősen elônyös helyzetben volt, mivel az országban már múködött bizonyos mértékú IKT-ipar. Majdnem valamennyi korábban állami tulajdonban volt szervezetnek megvolt a maga számítástechnikai központja, s a Tallinni Múszaki Egyetem és a Tartui Egyetem jó színvonalú informatikai oktatást nyújtott.

Az elsố számítógépeket Észtországban már az 1950-es évek végén és az 1960-as évek elején elkezdték gyártani és felhasználni. Az elsố számítógépközpontokat a Tartui Egyetemen (1959), a Kibernetikai Intézetben (1960) és a Tallinni Múszaki Egyetemen hozták létre. Az elsô és második generációs szovjet gyártmányú Ural és Minsk típusú számítógépeket felhasználták mind a tudományos kutatásban, mind az egyetemeken folyó informatikai oktatásban. Az 1980-as években az észt szakemberek részt vettek a Szovjetunió különböző minisztériumai számára készített sztenderd szoftverek kifejlesztésében (ideértve többek között a CASE-eszközöket). Az 1960-ban az Észt Tudományos Akadémia intézményeként létrehozott Kibernetikai Intézet például képes volt problémaorientált szoftverrendszerek kidolgozására is. Ma a Tallinni Múszaki Egyetem Kibernetikai Intézete interdiszciplinális kutatóintézetként múködik, amely a kontrollelmélet, az alkalmazott matematika és az elméleti mechanika, valamint a számítógéptudomány és az információs technológia egyes területeire, nevezetesen a programozási nyelvek elméletére, az idôzítéses és hibrid rendszerek specifikációjára és hitelesítésére, adatbázisok fejlesztésére és információs rendszerkutatásra specializálódott. Ez az intézet volt a motorja majdnem minden országos együttmúködési kezdeményezésnek az IKT területén.

A másik fontos kutatási és fejlesztési központ a Cybernetica $A S$, amely 1997-ben a Kibernetikai Intézetból vált ki. Ez a vállalat az információbiztonság (a kommunikáció biztonságát szolgáló termékek, például elektronikus aláíási technológiák), a rendszerhibák kiküszöbölésére szolgáló biztonsági megoldások (mission-critical systems) és különféle navigációs rendszerek fejlesztésével foglalkozik, s részt vett többek között az észtországi e-szavazási szoftver kidolgozásában is.

${ }^{48}$ Lásd Kalvet és Kattel 2006, 55-60 és 76-84.

${ }^{49}$ Suurna 2007. 
Az empirikus adatok általában azt mutatják, hogy az észt kutatási rendszer nemzetközi összehasonlításban nem erôs. 2005-ben a K + F-re fordított összes kiadás a GDP 0,9 százalékát tette ki, míg az EU-15 átlaga 1,9 százalék, az EU-27 átlaga pedig 1,8 százalék volt. A magánszektorban a K+F-kiadások a GDP 0,42 százalékának feleltek meg, míg ugyanez a mutató mind az EU-15, mind az EU-27 országok átlagában 1,2 százalék volt. ${ }^{50}$ Azok az észt iparágak, amelyekben a szektorra jellemzó hozzáadott érték a nemzeti GDP százalékában a legmagasabb, nem számítanak az úgynevezett K + F intenzív iparágak közé. Például míg a szállítás, raktározás és kommunikáció együttesen 10,6 százalékkal járul hozzá a GDP-hez (2005), és ezekben az ágazatokban a K + F intenzitás ${ }^{51}$ értéke csupán 0,1 ; a nagykereskedelem és a kiskereskedelem, valamint a gépjármúvek javítása terén az ennek megfelelố adatok 13,2 százalék, illetve 0,08 . A leginkább $\mathrm{K}+\mathrm{F}$ intenzív szektorok Észtországban a számítógépgyártás és a hozzá kapcsolódó kiszolgálótevékenységek, az elektromos és optikai berendezések gyártása, a vegyipar, valamint a szállítóberendezések gyártása. Különböző szakértốk egybehangzó véleménye szerint Észtországban körülbelül 50 világszínvonalú kutatásintenzív vállalat múködik, amelyek közül 10-15 tartozik az ITK-szektorhoz. ${ }^{52}$

Ha közelebbról szemügyre vesszük az észt informatikai kutatók publikációit és az ezekre utaló hivatkozásokat az ISI Web of Science adatbázisában, ${ }^{53}$ a következó általános megállapításokat tehetjük:

Elôször is, a Tartui Egyetem nemzetközi tudományos szintje az egy kutatóra jutó publikációk és referenciák számával mérve vitathatatlanul magasabb, mint a többi intézményé. ${ }^{44}$

4. táblázat

Azészt informatikai kutatók nemzetközi folyóiratokban megjelent közleményei, ISI Web of Science, 1979-2004.

\begin{tabular}{|l|c|c|c|c|c|c||}
\hline \multicolumn{1}{|c|}{ Intézmény } & $\begin{array}{c}\text { A kutatók } \\
\text { száma }\end{array}$ & $\begin{array}{c}\text { A közlemé- } \\
\text { nyek száma }\end{array}$ & $\begin{array}{c}\text { Referen- } \\
\text { ciák } \\
\text { száma }\end{array}$ & $\begin{array}{c}\text { Egy közle- } \\
\text { ményre jutó } \\
\text { referenciák } \\
\text { száma }\end{array}$ & $\begin{array}{c}\text { nyek és } \\
\text { referenciák } \\
\text { együtt }\end{array}$ & $\begin{array}{c}\text { Egy före } \\
\text { jutó átlag }\end{array}$ \\
\hline \hline Cybernetica & 13 & 11 & 10 & 0,9 & 21 & 1,6 \\
\hline $\begin{array}{l}\text { A Tallinni Múszaki Egyetem } \\
\text { Kibernetikai Intézete }\end{array}$ & 27 & 143 & 268 & 1,9 & 411 & 15,2 \\
\hline Tallinni Múszaki Egyetem & 91 & 149 & 168 & 1,1 & 317 & 3,5 \\
\hline Tartui Egyetem & 19 & 41 & 778 & 19,0 & 819 & 43,1 \\
\hline Tartui Egyetem & 18 & 27 & 44 & 1,6 & 71 & 3,9 \\
\hline Összesen: & 155 & 326 & 1202 & & & \\
\hline
\end{tabular}

Forrás: Kattel-Kalvet 2005, 52

\footnotetext{
${ }^{50}$ Eurostat 2007.

${ }^{51}$ A szektorális $\mathrm{K}+\mathrm{F}$ részaránya a szektor által termelt hozzáadott értékben.

${ }^{52}$ Lásd Gabrielsson et al. 2007, 3. fejezet.

${ }^{53}$ Részletesebben lásd Hakkaja 2005.

${ }^{54}$ Kalvet-Kattel 2006, 52.
} 
Másodszor: az észt informatikai kutatók által 1979 és 2004 között publikált közlemények több mint 80 százalékát összesen 10 személy adta közre (és ugyanezekre vonatkoznak a táblázatban feltüntetett referenciák is). Közülük négyen a Kibernetikai Intézetben, hárman a Tallinni Mưszaki Egyetemen múködnek, egy fớ a Tartui Egyetem oktatója, ketten pedig egyidejúleg két intézményben (a Tartui Egyetemen és a Kibernetikai Intézetben, illetve a Tallinni Múszaki Egyetemen és a Tartui Egyetemen) dolgoznak tudományos munkatársként. Ennek a 10 embernek a kutatási területei a következók: félvezetók, programozás, bioinformatika, optika és nem lineáris menedzseri rendszerek. Ugyanezekról a területekról mondhatjuk el tehát, hogy itt az észtországi informatikai kutatások nemzetközi színvonalon állnak. ${ }^{55}$

\section{Digitális szakadék}

A változások beköszöntése és az új technikai-gazdasági paradigma kialakulása idején mindig vannak gyớztesek és vesztesek. Egyes országok, lakossági csoportok, illetve személyek könnyebben alkalmazkodnak a változásokhoz, míg mások passzívabbak, sốt akár szembe is szállhatnak a változásokkal. A „digitális szakadék” kifejezés egy olyan veszélyre utal, amelyet az IKT-paradigma kialakulása hoz magával: ez a fajta „szakadék" a különböző társadalmi-gazdasági szinteken álló emberek, háztartások, vállalkozások vagy akár földrajzi térségek között jön létre az információs és kommunikációs technológiákhoz és az internethez való hozzáférési lehetôségeik tekintetében. A digitális szakadékban az egyes országok között és azokon belül fennálló többféle egyenlő́tlenség tükröződik. ${ }^{56} \mathrm{Az}$ IKT-paradigma kontextusában ez olyan helyzetet jelent, amikor a lakosság (vagy az országok) egy része a meglevő vagy éppen kialakulóban levő digitális szakadék miatt ténylegesen vagy várhatóan kirekesztớdik a további gazdasági és társadalmi fejlődésból és jólétból, amelyet az IKT térhódítása eredményez.

Egy 2002-ben megjelent tanulmány kimutatta, hogy az internetet nem használók között Êsztországban többségben vannak a „kékgallérosok” és az úgynevezett „passzív egyének”. A „passzív egyének” csoportját a következók jellemzik: többségük 50 éves vagy idôsebb, viszonylag csekély érdeklődést mutatnak a mindennapi életükön kívül esô dolgok iránt, és az internetre vagy a számítógépekre vonatkozó ismereteik minimálisak. Az internetnek nem látják semmi hasznát, és nincs szükségük a használatára, elốnyben részesítik a hagyományos médiát (még akkor is, ha az internet olcsóbb és kényelmesebb lenne), mivel az általános érdeklôdéshiánytól eltekintve korlátozza óket a nyelvismeret hiánya is, nem tudják kezelni a számítógépek felhasználói felületeit; emellett viszonylag kevéssé képesek új dolgokat megtanulni és memorizálni, és nem hajlamosak változtatni a szokásaikon. A „kékgallérosok” fóleg szakképzetlen dolgozók és szakmunkások, akiknek nincs szükségük számítógépre a munkájukban; az ehhez a csoporthoz tartozó embereknek körülbelül a fele nem lát semmi elónyt az internet használatában, és nem hajlamos mindennapi életvitelén változtatni. ${ }^{57}$

\footnotetext{
${ }^{55}$ Uo.

${ }^{56}$ OECD 2001. 5.

${ }^{57}$ Kalkun-Kalvet 2002.
} 
A nem felhasználók és még inkább a „passzív egyének” csoportjára vonatkozó fenti megállapításokat megerôsíti egy 2005-ben végzett vizsgálat konklúziója is, miszerint , ,...] azok az emberek, akik nem használták az internetet, többnyire az otthonra és a kertre orientált életmódot folytattak" ${ }^{58}$ A kutatók részletesen vizsgálták a tényleges internethasználat összefüggéseit az adott személyek életstílusával, és az internethasználat fóbb céljait a következő csoportokra osztották fel: „,sokoldalú fogyasztás”, „,kommunikáció és szórakozás”, „munka és tájékozódás”, „,szórakozás és családi kapcsolatok ápolása”, „közérdekú és gyakorlati információk keresése”. A fenti tevékenységekre orientált internetezók mellett külön típusba sorolták az „alkalmi felhasználókat”. Megállapították továbbá, hogy „az interneten végzett tevékenységek különböző aspektusai” további elemzést igényelnek. ${ }^{59}$

\section{Bizalom és információbiztonság a hálózatokon}

Az e-szolgáltatások biztonságosságába vetett bizalom tekintetében egy viszonylag új keletú vizsgálat Észtországban azzal a megdöbbentő eredménnyel zárult, hogy az internetfelhasználók 64 százaléka nem bízik az e-szolgáltatások biztonságos voltában. ${ }^{60}$ Ez éles ellentétben áll egy egész Európára kiterjedő korábbi vizsgálat eredményeivel, amelyek szerint Észtország egyike azoknak az országoknak, ahol a legkevesebb aggály merül fel az adatbiztonsággal és a magánéleti, illetve más bizalmas információk biztonságos kezelésével kapcsolatban (ebból a szempontból az első két helyen Bulgária és Magyarország állt). Észtországban a rendszeres internetfelhasználóknak csak 9 százaléka táplál súlyos kétségeket az adatbiztonság tekintetében, összehasonlítva a közép- és kelet-európai országok 24 százalékos és az EU-tagállamok átlagosan 26 százalékos arányával. (Ugyanez az arány Svájcban 20 százalékos, az Egyesült Államokban pedig 40 százalékos.) Hasonló eredményeket találtak a magánélet és a bizalmas információk vonatkozásában is. ${ }^{61}$

Az Észtországban tapasztalható aggályok alacsonyabb szintjét mutatták ki újabb páneurópai összehasonlításokban is. Azoknak a személyeknek az aránya, akik egyes fizetéssel járó múveleteknél (hitelkártya vagy bankkártya használatakor) csalárd eljárásokat tapasztaltak, illetve számítógépes vírus okozta adatveszteséget vagy idôveszteséget szenvedtek, az EU átlagos szintjénél alacsonyabb, ${ }^{62}$ továbbá - amennyire ez egyáltalán megállapítható - az utóbbi években Észtországban nem fordultak elő olyan, az adatbiztonság sérelmével járó komolyabb balesetek, amelyek megmagyaráznák ezt a jelentôs változást.

Jelenleg nem állnak rendelkezésre alaposabb vizsgálati eredmények arra nézve, hogy az észtek általában miért bíznak jobban az online tranzakciók biztonságosságában,

\footnotetext{
${ }^{58}$ Pruulmann-Vengerfeldt 2006, 39.

${ }^{59}$ Uo. 36.

60 TNS Emor 2005.

${ }^{61}$ Statistical Indicators Benchmarking the Information Society...

${ }^{62}$ Eurostat 2006.
} 
mint más országok állampolgárai. Ésszerú lehet azonban feltételezni, hogy a jelenlegi helyzet a fejlett és biztonságos megoldások meglétére vezethetố vissza, amelyeknek köszönhetốn a lakosság pozitív tapasztalatokat szerzett az online végrehajtott banki múveletek kapcsán, és a társadalomban kifejezetten pozitív kép alakult ki ebben a tekintetben. Még ha előfordultak is biztonsági problémák az online szolgáltatások igénybevételekor, ezeket mind technikailag, mind a publicitás szempontjából mindenki számára kielégítô módon kezelték. Ez olyan helyzetet teremtett, amelyben az emberek nem félnek igen érzékeny információk (például politikai referenciák) feltárásától sem az interneten, és kivételesen jó alapok jöttek létre az e-szavazási mechanizmusok továbbfejlesztéséhez.

A kiberbúnözés ${ }^{6.3}$ elleni védekezésre kezdettól fogva nagy gondot fordít az észt információs társadalom valamennyi fốbb szereplôje. Ez a törekvés húzódott meg az észt elektronikus aláírási infrastruktúra és a személyazonosító kártyák bevezetése mögött, és a bankok is igen aktívan bekapcsolódtak a kiberbúnözés veszélyeinek fokozott tudatosításába a lakosságban.

Ezen a téren a legújabb lépés a „Számítógép-védelem 2009” elnevezésú kezdeményezés, ${ }^{64}$ melynek nyíltan vállalt célja az, hogy Észtországban épüljön ki a legbiztonságosabb információs társadalom.

A hálózati és információs biztonsággal összefüggő kérdések természetesen nagyrészt globális természetúek. A kiberháború olyan helyzetet teremt, amelyben az egymással hadban álló nemzetek vagy terroristacsoportok támadásokat intéznek a sebezhetô számítógépes hálózatok ellen. 2007 áprilisában és májusában az észtországi számítógép-hálózatok éppen ilyenfajta támadásoknak voltak kitéve a szovjet korszakban felállított háborús emlékmú eltávolítása kapcsán Oroszországgal támadt feszültséget követốen. Mindmáig nem tisztázódott le, hogy a kibertámadások állami kezelésben levó számítógép-hálózatokból, Oroszországból indultak-e ki, vagy ez a támadás nagy technológiai tudású aktivisták (vagy „hactivisták”) múve volt. Akárhogyan is történt, tény, hogy rejtett kódok útján számítógépek sokaságát bénították meg, elárasztva óket hamis információkérésekkel. Ez a „szolgáltatások széles körú szüneteltetésével” (Distributed Denial of Service, DDOS) járó támadássorozat, amely a csúcspontján több mint egymillió számítógépet érintett Észtországban, egyes célpontok esetében másodpercenként ötezer kattintásnak megfelelő forgalmat eredményezett, és leblokkolta a bankokhoz és kormányhiva-

${ }^{63}$ A kiberbúnözés kifejezés széles körben használatos az olyan tevékenységek leírására, amelyekben a számítógépek vagy számítógépes hálózatok búncselekmények eszközéül, célpontjául vagy helyszínéül szolgálnak. Lásd Council of Europe 2001.

${ }^{64} 2006$ májusában a legnagyobb bankok (SEB, Eesti Ühispank, Hansapank) és távközlési szolgáltatók (Elion, EMT), valamint a Gazdasági és Kommunikációs Minisztérium egyezményt írtak alá egy országos kezdeményezés elindításáról, a végfelhasználóként alkalmazott személyi számítógépek védelméról és az ezzel kapcsolatos problémák tudatosításáról Észtországban. Ennek jegyében számos alprojektet fognak indítani (e vállalatok részéról 3,7 millió eurónyi összeggel finanszírozva), amelyek középpontjában az e-szolgáltatások igénybevételekor alkalmazott személyazonosítókártya-alapú hitelesítés továbbfejlesztése áll. 2007. május 2-án a bankok felállítottak egy korlátot a jelszavas kártyákkal indított pénzügyi tranzakciók összeghatárára: a 640 eurót meghaladó értékú tranzakciók lebonyolításához PIN-kalkulátort, csak egyszer felhasználható jelszavas kártyát vagy - a bankok javaslata értelmében - személyazonosító kártyát kell felhasználni. 
talokhoz való hozzáférést. Ezenkívül - annak érdekében, hogy a helyi felhasználók számára nyitottan tudja tartani a hálózatot - Észtországnak el kellett zárnia az internetes honlapjaihoz való hozzáférést a külföldról érkező megkeresések előtt. ${ }^{65}$

\section{Diszkusszió: a magyarázatok keresése felé}

Az 1990-es évek óta Észtország figyelemre méltó sikereket ért el az információs társadalom fejlődésében. Az internethasználat viszonylag rövid idő alatt meredeken felszökött, és az e-szolgáltatások és m-szolgáltatások megtalálták a helyüket Észtország lakosságának és gazdasági vállalkozásainak mindennapi életében. Az alábbiakban röviden áttekintjük Észtország információs társadalommá történő átalakulásának fóbb vonásait, az „észt modell” kifejezést az ebben a folyamatban kulcsszerepet játszó elemek és a köztük fennálló kapcsolatok összefoglaló megjelölésére alkalmazva. ${ }^{66}$

Az információs társadalom fejlődését befolyásoló, illetve ahhoz hozzájáruló fóbb tényezók közül Észtország esetében a gazdasági szereplóket, az állami szektor aktív szerepét, a technológiai szakértelmet és a szociokulturális tényezóket kell kiemelni. Az utóbbiak hozzájárulása szorosan összefügg az IK'T- és az IK'T-alapú szolgáltatások iránti kereslettel, amellyel más tanulmányokban foglalkozunk. ${ }^{67}$

\section{Az általános gazdasági növekedés hatásai}

A piaci reformok sorozatának és a makroökonómiai stabilitás viszonylag gyors elérésének eredményeként az észt gazdaság 1995 óta évente átlagosan több mint 6 százalékkal növekedik, és 2005-ben 10,5 százalékos, 2006-ban pedig 11,4 százalékos növekedési csúcsot ért el, ${ }^{68}$ ami az Európai Unióban a legjobb teljesítmények közé számít. Az egy fớre jutó GDP, amely Észtországban a vásárlóerô-paritást is figyelembe véve 2003-ban az EU-25 átlagának 51 százalékát tette ki, 2006-ig az uniós átlag 65 százalékára emelkedett. ${ }^{69}$

Az ilyen gyors gazdasági növekedés és annak közvetlen hatásai (például az állami adójövedelmek növekedése, ami lehetôvé tette az állami IK'T-befektetések finanszírozását), valamint az ebból eredő közvetett hatások (például az életszínvonal emelkedése és ennek folytán az otthoni IK’T-infrastruktúra széles körú elterjedése) feltétlenül pozitívan befolyásolták az észt információs társadalom fejlődését. Noha vannak olyan országok, amelyekben gyors a gazdasági növekedés, de az információs társadalommal összefüggő́ fejlemények lassabban alakulnak ki, ez a két tendencia általában összekapcsolódik egymással, mivel a „kenyeret vagy széles sávot” dilem-

${ }^{65}$ Lásd Economist 2007a és 2007b.

${ }^{66}$ Értékelésünkre ösztönzóen hatott Castells és Himanen (2002) munkája; az információs társadalom finn modelljéról adott elemzésüket lásd könyvük 7. fejezetében.

${ }^{67} \mathrm{Az}$ internetfelhasználók és az internethasználat részletesebb tárgyalását illetốen, beleértve az új médiával kapcsolatos fejleményeket is, lásd Pruulmann-Vengerfeldt 2006.

${ }^{68}$ Eurostat 2007.

${ }^{69}$ Uo. 
mával szembekerülve valószínúleg senkinek sem kell sokáig gondolkodnia, hogy melyiket válassza. Az a feltételezés, hogy az IKT pozitív szerepet játszik az észt gazdasági növekedés mögött meghúzódó termelékenységi robbanásban, további igazolást igényel, de a már rendelkezésre álló adatok is alapot adnak ilyen következtetések levonására.

\section{A távközlés és a bankszektor}

Mint említettük, az észt információs társadalom fejlődésének zászlóshajói a távközlés és a bankszektor. A vezetố vállalatok ezekben a szektorokban jelentôs összegú külföldi tókebefektetésekben részesültek, és jelenleg a legnyereségesebb és leginnovatívabb vállalatok közé tartoznak Észtországban. Ennek köszönhetően igen fejlett, de ugyanakkor elfogadható árú szolgáltatásokat kínáló távközlési hálózat jött létre. Az észt bankszektor - tudatában lévén annak, hogy a kapitalista gazdaságok számára döntô fontosságúak a jól múködő bankok - a hagyományos pénzügyi szolgáltatások nyújtása mellett erốteljes kezdeményezéseket valósított meg a modern e-szolgáltatások bevezetése terén, hasonló színvonalú e-szolgáltatások iránti várakozásokat teremtve mind a magán-, mind az állami szektor más szervezeteinél is.

E két szektor vezetố vállalatai messze túlléptek azon, hogy csupán a saját üzleti ügyeikre koncentráljanak. Bár tevékenységeiket a „nagyvállalati társadalmi felelôsség” mintapéldáinak nevezni talán túlságosan is nagylelkú minősítés volna, kétségtelen, hogy számos olyan tevékenységet indítottak be, amelyek az egész társadalom érdekeit szolgálják. Ezek a vállalatok álltak például a Look@World kezdeményezés mögött, amely százezer ember alapvetố IKT-képzéséról gondoskodott Észtországban, majd részt vettek az Észt Informatikai Fóiskola létrehozásában. Jelenleg bekapcsolódtak a „Számítógép-védelem 2009” elnevezésú kezdeményezés végrehajtásába is. Az állami és a magánszféra együttmúködésének (Public Private Partnership, PPP) klasszikus példáját jelenti az észt elektronikus aláírási infrastruktúra kiépítésében való közremúködésük az általuk létrehozott Hitelesítési Központ útján.

A bank- és a távközlési szektor fenti robbanásszerú növekedése mellett jelentős fejlódés ment végbe a nagykereskedelem és kiskereskedelem, valamint más üzleti szolgáltatások terén is, vagyis éppen azokban a szektorokban, ahol más országokból származó empirikus adatok a legnagyobb IT-befektetések és pozitív externáliák jelenlétét mutatják.

\section{Az állami szektor aktív szerepe}

Az állami szektor szerepe igen fontos a társadalom fejlődésében. Az állam feladata a lépéstartás az IKT-paradigma kibontakozásával, megfelelő kereteket biztosítva valamennyi szektor számára a fejlődéshez a digitális szakadék kialakulásának megelốzésével és önmaga folyamatos modernizálásával.

Az észt állami szektor két nagyobb horizontális projektet indított meg, amelyek igen fontosnak bizonyultak az állami intézmények modernizálása szempontjából. Elő- 
ször a kormányzati információs rendszerek és adatbázisok rákapcsolódása történt meg az internetre az $X$-Road néven ismert szolgáltatási csomag révén. Másodszor: az elektronikus hitelesítési és felhatalmazási funkciókra is alkalmas személyazonosító kártyák valamennyi észt állampolgár számára kötelezô személyazonossági dokumentumként való bevezetése megteremtette az alapot számos innovatív e-szolgáltatás bevezetéséhez. Ezek a szolgáltatások emellett közvetlen lökést adtak hasonló fejlemények eléréséhez a magánszektorban is.

Az észt állam tevékenysége általánosságban ugyan nem állítható párhuzamba az úgynevezett ,fejlesztốállamokéval” (amelyek aktív beavatkozásokkal ösztönzik az ipari átalakulásokat, sốt néha vezetố szerepet játszanak azokban), ${ }^{70}$ de az állami szektorból eredő számos IKT-kezdeményezés (köztük az e-szavazás) esetében az állam „öntevékeny aktorként" lépett fel. Megfigyelhetô továbbá, hogy a magán- és az állami szektor közötti dinamikus kapcsolatok elôsegítik az állami közbeszerzési eljárások fontos innovációs politikai eszközként való felhasználását. ${ }^{71}$

\section{Technológiai kompetencia}

Az országban rendelkezésre álló IKT-készségek és K + F-kompetenciák nélkül, amelyek nagy része a szovjet korszak öröksége volt, a korábban említett sikerek az e-kormányzat vagy a $\mathrm{K}+\mathrm{F}$ intenzív termékek és szolgáltatások kifejlesztésében nem lettek volna elérhetốk. A Tallinni Múszaki Egyetem, a Kibernetikai Intézet és a Cybernetica egyaránt aktívan részt vesz majdnem minden országos együttmúködésre épüló kezdeményezésben az IKT területén. Ugyanakkor számos újabb kezdeményezés is született az informatikai ismeretek szintjének növelésére az iskolákban (pl. az említett „Tigrisugrás”) és a nagyközönség körében is (Look@World Internet Training).

Noha a külföldi vállalatok az 1990-es évek közepe óta igen aktívak az észt IKT-piacon, és részt vesznek az e-megoldások kifejlesztésében is, még mindig a hazai vállalatok játszanak kulcsszerepet. Az e-bankolás tekintetében olyan helyzet állt elő, hogy az Észtországban kifejlesztett és bevezetett megoldásokat ma már más országok is alkalmazzák, miután a legnagyobb észt bankok integrálódtak a fóbb pénzügyi központok hálózataiba (vagyis ebben az esetben fordított irányú technológiatranszfer valósul meg).

Az innovációs kultúra kezdettól fogva döntô szerepet játszik a jelenlegi legsikeresebb IK'T-alapú alkalmazások és szolgáltatások kialakulásában. Himanen ezt nevezi „hackeretikának”, amelyben megjelenik a kreatív hajlamok kiélésének vágya, az emberek önmaguk korlátainak állandó meghaladására való törekvése valamilyen kreatív munka eredményeként létrejövő alkotások felmutatása révén. ${ }^{72}$ Észtországban az „erkölcsös hackerek” lehetôséget kaptak elképzeléseik megvalósítására mind az állami, mind a magánszektorban.

${ }^{70}$ Részletesebben lásd Evans 1995 és Wade 2003.

${ }^{71}$ Lásd Edler-Georg Hiou 2007.

${ }^{72}$ Himanen 2001. Ez a szemlélet hasonló Schumpeter híres leírásához az olyan vállalkozókról, akiknek a motivációja túlmutat a maximális profit elérésére való törekvésen, és magában foglalhatja „egy magánkirályság, sốt - rendszerint, bár nem szükségképpen - egy dinasztia megalapításának álmát”. Ebbe beletartozik „a 


\section{Stratégia, politika és szabályozás}

Az információs társadalom és a tudásalapú gazdaság kiépítésére irányuló törekvések hosszabb múltra tekintenek vissza az észt politikában, bár az ilyen irányú fejlődés támogatására alkalmazott konkrét politikai eszközök száma meglepóen alacsony. Ez alól kivételt képez az 1990-es évek eleje, amikor ilyen értelemben ,jó kormányzás” valósult meg: az 1989-ben létrehozott Informatikai Tanácsban részt vettek a magánszektor képviselói is, és a tanácsnak valódi hatásköre volt a kezdeményezés koordinálása és bevezetése terén. ${ }^{73}$

A stratégiai partnerek bevonása és a távközlési piac liberalizálása érdekében tett kormányzati lépések döntố fontosságúak voltak, továbbá jelentốsen kedvezô hatást gyakorolt a fejlődésre az is, hogy a parlament által jóváhagyott törvényerejű szabályozások zöld utat adtak az olyan kulcsfontosságú horizontális projekteknek, mint például az elektronikus funkciókkal felszerelt személyazonosító kártyák és az e-szavazás bevezetése.

Az észt információs társadalmi politika fóként a társadalmi kérdésekre és a közigazgatás modernizálására koncentrál, másfelól azonban a $\mathrm{K}+\mathrm{F}+\mathrm{I}$ politika középpontjában az állami K + F-létesítményektól származó tudás kereskedelmi hasznosítása áll. ${ }^{74}$ Újabban nagyobb változások figyelhetớk meg az információs társadalmi politika jellegében, ami szélesebb körben folytatott társadalmi egyeztetésekre és vitákra támaszkodik, és összehangolt együttmúködésre törekszik más szakpolitikákkal (például a vállalati támogatás vagy az oktatáspolitika területén). Mindebben az EU strukturális alapjaiból származó összegek felhasználására irányuló tervezés átfogó logikája érvényesül. Az utóbbi években az észt $\mathrm{K}+\mathrm{F}+\mathrm{I}$-politika egyre inkább vállalkozásbaráttá válik: a 2007-2013. évi K + F + I-stratégia újabb országos programokat irányoz elố a kulcsterületeken, és 2007-ben az illetékes minisztériumok már megtették az elsố lépéseket is, amelyek további lökést adhatnak a magánszektor hasonló irányú fejlődésének.

\section{Javaslatok további kutatásokra az információs társadalom témakörében}

Az információs társadalom kutatása terén még ma is több fontos technikai és nem technikai kérdés igényel további vizsgálatokat. Az észtországi tapasztalatok alapján a következóket kívánjuk kiemelni:

A legnagyobb kihívást jelentő kérdést talán az IK'T-nak a gazdasági fejlődéshez való közvetlen hozzájárulási lehetôségei jelentik. Noha általános egyetértés van azt illetôen, hogy az észt gazdaság a fejlettebb országokból importált új technológiák, munkaszervezési módszerek és know-how alkalmazása útján sikeresen felzárkózott az élvonalhoz, tanulmányok egész sorozata bizonyítja, hogy az Európai Unió lisszaboni stra-

\footnotetext{
hódítás vágya, a harci készség, a mások legyôzésére való törekvés annak bizonyítására, hogy különbek vagyunk másoknál, egyszóval a siker vágya, nem az abból eredô haszonért, hanem magának a sikernek a kedvéćrt”. Ugyanilyen fontos lehet ,a teremtésnek, a dolgok megvalósításának az élvezete, vagy egyszerúen csak az ember energiáinak és képességeinek latba vetése fölött érzett öröm” is (Schumpeter 1934, 93).

${ }^{73}$ Bár az Európai Tanács továbbra is tanácsadóként működik a köztársaság kormánya mellett, szerepe esökkent, és 2005 óta nem ülésezik.

${ }^{74}$ Kattel-Kalvet 2006, 11, lásd továbbá Radosevic-Reid 2006.
} 
tégiájában javasolt gazdasági, társadalmi és környezeti megújulás megvalósítása terén igen nagy kihívások állnak az ország elốtt. Ahhoz, hogy az ország meg tudjon felelni ezeknek, gazdasági változásokra és a „tanuló társadalom” motorjaként szolgáló innovációk fokozott felhasználására van szükség. Egyes tanulmányok szerint ${ }^{75}$ az észt ipar technológiai struktúrája az 1990-es évek közepe óta kevésbé összetetté vált, „ez viszont ráirányítja a figyelmet arra, hogy - a gazdasági növekedés irigylésre méltó eredményei dacára - Észtország ipari struktúrája 1996-ban jobb állapotban volt, mint 2000-ben”. ${ }^{76}$

Az Észtországban bevezetett egyik legvitatottabb e-szolgáltatás az elektronikus szavazás az internet útján. Úgy túnik, hogy Észtország az Európai Unió egyetlen olyan tagállama, ahol törvény van érvényben az országos választások elektronikus úton való lebonyolítására, és Észtország volt az első ország a világon, amely lehetôvé tette állampolgárai számára, hogy az ország egész területén az interneten keresztül adhassák le szavazatukat a politikai választások alkalmából. Ezzel kapcsolatban azonban számos probléma további kutatásokat igényel. Elôször is, fennmarad a biztonság kérdése. Az e-szavazási megoldásokkal kapcsolatos valamennyi beszámoló hangsúlyozza ezt a kérdést, és vannak olyan jelentések is, amelyek a még megoldatlan biztonsági kérdésekre való tekintettel az internetalapú szavazással kapcsolatos kísérletek beszüntetését javasolják. Az észtországi személyazonosító kártyákra alapozott elektronikus aláírási infrastruktúra minden bizonnyal kivételes, és ebból fakadóan a biztonsági kockázatok marginálisnak tekinthetốk, ám további kutatásokra szükség lehet.

Kétségek merülnek fel továbbá azt illetôen is, hogy az ilyen társadalmilag érzékeny megoldásokat szükséges-e a továbbiakban is alkalmazni, és vajon megalapozottak és aktuálisak-e az e-szavazás bevezetését azon az alapon érố bírálatok, hogy ez a módszer összeütközésbe kerül a választások titkosságának, általánosságának és egységességének az alkotmányban rögzített elveivel. Sokan hangoztatják az esetleges technikai problémákból fakadó veszélyeket is. ${ }^{77}$

Egy másik, az állami szektorral összefüggó kérdés a koordináció problémáit veti fel. Az észtországi tapasztalatok elemzése azt mutatja, hogy az IKT alkalmazásai terén a különféle funkciók, szintek és szektorok koordinációja mindmáig megoldatlan maradt. A nagyobb mértékú koordináció hierarchikus hálózati vagy piaci eszközökkel érhetố el. A „, felülról gyakorolt hatalom” klasszikus modellje mellett felhasználható a szolidaritásra és az önkéntes együttmúködésre alapozott hálózati modell is, ez azonban feltételezi, hogy a célok széles körben elfogadottak legyenek a hálózat valamennyi tagja részéról. Azt a kérdést, hogy az IKT fejlődésének koordinációjához Észtországban mi lehetne a legjobb modell, tovább kell vizsgálni. Mivel azonban az észt államigazgatás céljaival valójában nem mindenki tud azonosulni, a hálózati modell valószínúleg nem múködik. Lehetséges, hogy inkább a civilszervezetek és a piaci szereplók közös jövóképére kellene koncentrálnunk ahelyett, hogy a hierarchikus megoldás és a piac között választanánk? A közös jövôkép központi szerepet játszik a finn modell sikerében. ${ }^{78}$

Észtországot sikeresnek tartják az e-kormányzati megoldások bevezetése terén. Ám a fejlődés lelassulása az utóbbi években sürgeti más országok tapasztalatainak elemzését és

\footnotetext{
${ }^{75}$ Lást például Tiits et al. 2003.

${ }^{76}$ Uo. 27

${ }^{77}$ Lásd Drechsler-Madise 2004.

${ }^{78}$ Castells és Himanen 2002.
} 
az ezekból adódó tanulságok levonását, ami például az m-szolgáltatások területén már megtörtént, hasznos eredményekkel. Egy másik szempontból ugyanakkor Észtország sikerei az e-kormányzás terén sok országot arra késztettek, hogy mérlegeljék az észt modell átvételének lehetôségeit saját maguk számára. E két kutatási irány szorosan összefügg.

Az észt állami szektorban alkalmazott IKT-megoldások költséghatékonysági elemzése és értékelése mindeddig erôsen korlátozott mértékư volt. Ez részben a költségadatok hozzáférhetetlenségének tulajdonítható, de bizonyára szerepet játszik benne az alkalmas módszerek ismeretének és az e téren másutt már meglevố hagyományok hiánya is. Ebból adódóan az értékelés és a költség-haszon elemzés terén több kutatásra van szükség, és az eddig követett politika elemzése hozzájárulhat egy igen fontos kérdés megválaszolásához: vajon hatékonyan történik-e az IKT felhasználása, és az nagyobb átláthatóságot és elszámoltathatóságot eredményez-e?

A technológiatranszfer tekintetében is számos kérdés merül fel. Az elméleti irodalom azt ajánlja, hogy túl kell lépni a „legjobb gyakorlatok” terjesztésének széles körben alkalmazott, ám a problémákat leegyszerúsítô módszerén. Ugyanakkor az innovációkutatás területén jól ismert, hogy sokat számítanak az olyan tényezók, mint például a normák, a szokások és a bevett szabályok, ${ }^{79}$ és ennélfogva a közvetlen transzfer lehetetlen. „Egy másutt hatékonynak bizonyult program átvétele nem garancia a sikerre": ${ }^{80}$ ehelyett a benchmarking, a „legjobb gyakorlatok” tanulmányozása, valamint a tanulságok levonása lehet irányadó. A további kutatásoknak meg kell határozniuk, hogy Észtország számára mely „legjobb gyakorlatok” vehetók át máshonnan, illetve melyek a másutt Észtországtól átvehetố megoldások. Az észt elektronikus aláirási infrastruktúra például nem másolható le olyan országokban, amelyek nem bocsátanak ki kötelezóen előírt személyazonosító kártyát, és amelyeknek a polgárai nem mutatnak kelló bizalmat ezek bevezetése iránt. Mindezek a kontextusfüggő kérdések sokat számítanak, és tovább vizsgálandók.

Az e-szolgáltatások potenciálisan megteremtik sok hagyományos gyakorlat megváltozásának az esélyét a társadalomban, ezért az idevágó társadalmi és etikai kérdéseket is tovább kell kutatni. Ez különösen igaz az egészségügyi ellátás tekintetében, ahol egyesek szerint erôsen megfogyatkozott a betegeknek az orvosokba vetett bizalma, és terjedóben van a a rögzített információk fetisizálása. További problémák merülhetnek fel, ha az emberek magánúton másokkal megosztott egyéni egészségügyi adatait egyszersmind például közigazgatási vagy más kormányzati célokra is felhasználhatják a politikai döntéshozók, akik ugyanakkor a növekvố egyéni felelősséget hirdetik az adatbiztonság tekintetében. Néhány további, inkább technikai jellegú kérdés az integráció és az interoperabilitás nemzetközi szintû megteremtésével és az úgynevezett „,örnyezeti intelligencia" (ambient intelligence) nyelvi technológiáival áll kapcsolatban.

A digitális megosztottság továbbra is problémát jelent Észtországban, és úgy tûnik, hogy az internetfelhasználók körében is különbözó profilok alakulnak ki: egyesek csupán a szórakozásra orientált felhasználási lehetőségeket kedvelik, figyelmen kívül hagyva az állami és a magánszektor elérhető szolgáltatásainak széles választékát. Ezért foglalkoznunk kell a digitális megosztottság leküzdésével, és fokozni kell a meglevő e-szolgáltatások tudatosítását a társadalomban.

${ }^{79}$ Lásd például Lundval 1995.

${ }^{80}$ Rose 1993, ix. 
Végül sürgôs kezelést igénylő kérdéssé vált a hálózati biztonság problémaköre is. Noha ezzel a kérdéssel sok nemzetközi szervezet foglalkozik, egyelöre még messze vagyunk a kiberbúnözéssel kapcsolatos nemzetközi törvények széles körû elfogadásától. ${ }^{81}$ Az interneten és általában a kibertérben folyó tevékenységek, köztük a kiberháborúk szabályozásának lehetôségeit mindmáig csak részlegesen vizsgálták.

\section{Irodalom}

Accompanying document to the i2010 - Annual Information Society Report 2007. 2007 Commission of the European Communities, http://ec.europa.eu/information_society/eeurope/i2010/docs/ annual_report/2007/sec_2007_395_en_documentdetravail3_p.pdf, 2007.

Alec, Charles 2004. Estonia - the State of the e-state. The Baltic Times, 22 July, http://www.baltictimes.com/news/articles/10522/

Bank of Estonia. 2007. On-line Database.

Centeno, Clara 2004. Adoption of Internet services in the Acceding and Candidate Countries, Lessons from the Internet Banking Case. Telematics and Informatics, 21, 293-315.

Certification Centre (AS Sertifitseerimiskeskus), personal communication, August 2007.

Council of Europe. 2001. Convention on Cybercrime, http://conventions.coe.int/Treaty/EN/Treaties/HTML/185.htm

Drechsler, Wolfang - Ülle Madise. 2004. Electronic Voting in Estonia. In: Kersting, Norbert Baldersheim, Harald (eds.), Electronic Voting and Democracy. A Comparative Analysis. Basingstoke, Palgrave Macmillan, 97-108.

Dutta, Soumitra - Mia, Irene Global Information Technology Report 2006-2007: Connecting to the Networked Economy. New York, Palgrave Macmillan.

Economist. 2007. Newly nasty, May 24th.

Economist. 2007. A cyber-riot, May 10th.

Economist Intelligence Unit 2006. The 2006 e-readiness rankings, A white paper from the Economist Intelligence Unit. http://a330.g.akamai.net/7/330/25828/20060531184642/graphics.eiu.com/ files/ad_pdfs/2006Ereadiness_Ranking_WP.pdf

Edler, Jakob - Georghiou, Luke2007. Public procurement and innovation - Resurrecting the demand side. Research Policy.

Estonian Information Society Development Strategy 2013. 2006. Ministry of Economic Affairs and Communications, http://www.riso.ee/en/files/IYA_ENGLISH_v1.pdf

Estonian Research, Development and Innovation Strategy 2007-2013 (Eesti teadus- ja arendustegevuse ning innovatsiooni strateegia 2007-2013). 2007. Riigikogu (Parliament), http://web.riigikogu.ee/ems/saros-bin/mgetdoc?itemid=063390023\&login= proov\&password=\&system $=$ ems\&server=ragne11, February

Estonian Research and Development Strategy 2002-2006, 2002. Research and Development Council, http://vana.hm.ee/uus/hm/client/index.php?1352671823229

Estonian Tax and Customs Board. 2007. Estonian Tax and Customs Board Yearbook 2006. http://www.emta.ee/doc.php?21262

Eurostat. 2007. Eurostat On-line Database.

Hakkaja, Kristi 2005. Estonian ICT Research and its Impacts - Bibliometric Analysis, PRAXIS Working Paper No 22. PRAXIS Center for Policy Studies.

Hansen, John - Sorsa, Piritta 1994. Estonia: A Shining Star from the Baltics. In Michalopoulos, Constantinea - Tarr, David G. (eds.): Trade in the New Independent States. Washington, DC World Bank. 
Högselius, Per 2005. The Dynamics of Innovation in Eastern Europe: Lessons from Estonia. Cheltenham, UK and Northampton, MA, USA, Edward Elgar Publishing.

Information Society Benchmarking Report. 2005. European Commission, http://europa.eu.int/information_society/eeurope/i2010/docs/benchmarking/ 051222\%20Final\%20Benchmarking\%20Report.pdf

Information Technology in Public Administration of Estonia. Annual Report 1994-2005, Tallinn, Estonian Informatics Centre. http://www.riso.ee/en/publications/natpublications

Kaasik, Ülo 2003. Eesti eksporditoodete lisandväärtus (Value-added of Estonian Export Commodities).Tallinn, Eesti Pank.

Kalkun, Mari - Kalvet, Tarmo (eds.) 2002. Digital Divide in Estonia and How To Bridge It, Tallinn, PRAXIS Center for Policy Studies.

Kalvet, Tarmo 2004. Private Sector R\&D in the Nero Member States: Case of Estonia. Framework Service Contract 150083-2005-02-BE with the Institute for Prospective Technological Studies Directorate General Joint Research Centre, European Commission. Brussels, European Techno-Economic Policy Support Network.

Kalvet, Tarmo 2004. The Estonian ICT Mamufacturing and Software Industry: Current State and Future Outlook. Seville, Institute for Prospective Technological Studies - Directorate General Joint Research Centre, European Commission.

http://www.jrc.es/home/publications/publication.cfm?pub=1200

Kalvet, Tarmo 1997. Theoretical Issues and Practical Plans of Information Policy in Developed Countries. BA Thesis. Tartu, University of Tartu.

Kalvet, Tarmo - Aaviksoo, Ain 2007. Next Steps in Developing Information Society Services in the New Member States. The Cases of eGovernment and eHealth in Estonia. Seville, Institute for Prospective Technological Studies - Directorate General Joint Research Centre, European Commission.

Kalvet, Tarmo - Pihl, Tarmo - Tiits, Marek 2002. Analysis of the Estonian ICT Sector Innovation System. Executive Summary. Tartu, Archimedes Foundation.

Kattel, Raincr - Kalvet, Tarmo 2006. Knowledge-based Economy and ICT-Related Education: Overview of the Current Situation and Challenges for the Education System. Tallinn, PRAXIS Center for Policy Studies.

Kerem, Katri 2003. Internet Banking in Estonia. PRAXIS Working Paper No 7/2003. http://www.praxis.ee/data/PRAXIS_Internet_Banking_in_Estonia0.pdf

Klaamann, Vaho 2007. Eesti IKT sektori analiiis 2005 aasta andmete põhjal (Study of Estonian ICT sector based on 2005 data. Tallinn, Estonian Association of Information Technology and Telecommunications.

Koski, Heli - Rouvinen, Petri - Ylä-Anttila, Pekka 2002. ICT Clusters in Europe. The great central banana and small Nordic potato. Information Economics and Policy, 14, 145-165.

Krull, Andre 2003. ICT Infrastructure and E-readiness Assessment Report: Estonia. PRAXIS Working Paper No 5/2003. Tallinn, PRAXIS Center for Policy Studies.

Levy, Steven 2007. True or False: U.S.'s Broadband Penetration Is Lower Than Even Estonia's. Newsweek, July 2-9.

OECD Reviews of Foreign Direct Investment, Estonia. 2001. Paris, OECD.

Online Availability of Public Services: How Is Europe Progressing? Web Based Survey on Electronic Public Services Report of the 6th Measurement. 2006. http://ec.europa.eu/information_society/ eeurope/ i2010/docs/benchmarking/online_availability_2006.pdf

Online Availability of Public Services: How is Europe Progressing? Web Based Survey on Electronic Public Services. Report of the Fifht Measurement. 2005. October 2004. Capemini.

http://ec.europa.eu/information_society/soccul/egov/egov_benchmarking_2005.pdf, 
Pruulmann-Vengerfeldt, Pille 2006. Information Technology Users and Uses within the Different Layers of the Information Environment in Estonia. PhD Thesis. Tartu, University of Tartu Press.

Principles of the Estonian Information Policy 2004-2006. Estonian IT Policy: Towards a More ServiceCentred and Citizen-Friendly State. 2004. http://www.riso.ee/en/Information_Policy_04.pdf

Principles of Estonian Information Policy, RTI 1998, 47, 700.

Radosevic, Slavo - Reid, Alasdair 2006. Innovation Policy for a Knowledge-based Economy in Central and Eastern Europe: Driver of Growth or New Layer of Bureacracy? In Piech, Krzysztof - Slavo Radosevic (eds.):, The Knowledge-based Economy in Central and Eastern Europe. New York, Palgrave Macmillan, 295-311.

Rannu, Rain 2005. Mobile Services in Estonia. PRAXIS Working Paper no 8. http://www.praxis.ee/data/PRAXIS_Mobile_Services_in_Estonia3.pdf

Rannu, Rain - Semevsky, Maarja 2005. Mobile Services in Tartu. Existing services, best practices, methodology and suggestions for future development. Tartu, Mobi Solutions. http://www.ega.ee/public/Mobile_services_in_Tartu_FINAL1.pdf

Schumpeter, Joseph A. 1934. Theory of Economic Development. An Inquiry into Profits, Capital, Credit, Interest, and the Business Cycle. Cambridge, MA, Harvard University Press.

Statistical Office of Estonia. 2007. On-line Database, www.stat.ee

Sung-Bae Mun - Nadiri, Ishaq M. 2002. Information Technology Externalities: Empirical Evidence From 42 U.S. Industries. NBER Working Paper No. 9272. http://www.nber.org/papers/w9272

Suurna, Margit 2007. The Influence of Quangos on National Innovation Systems - Case Studies of the Estonian Genome Project and the e-Learning Initiatives. Master Thesis. Tallinn, Tallinn University of Technology.

The National Election Committee 2006. Municipal elections. http://www.vvk.ee/english/report2006.pdf

Tiits, Marek - Kattel, Rainer - Kalvet, Kaarli, Tarmo - Rein 2003. Competitiveness and Future Outlooks of the Estonian Economy. Tallinn: Research and Development Council.

TNS EMOR. Gallup e-Ratings, Estonia. 1998-2007.

UN Global E-Governement Readiness Report Readiness Report 2005. From E-Governement to E-Inclusion. 2005. Department of Economic and Social Affairs Division for Public Administration and Development Management. New York, United Nations. http://unpan1.un.org/intradoc/groups/public/documents/un/unpan021888.pdf

Wade, Robert 2003. What strategies are viable for developing countries today? The World Trade Organization and the shrinking of 'development space'. Review of International Political Economy. 10, 4, 621-644. 